\title{
Making a house a home: \\ Motivations for earthquake strengthening domestic homes in Dunedin, an argument towards Domestic Heritage
}

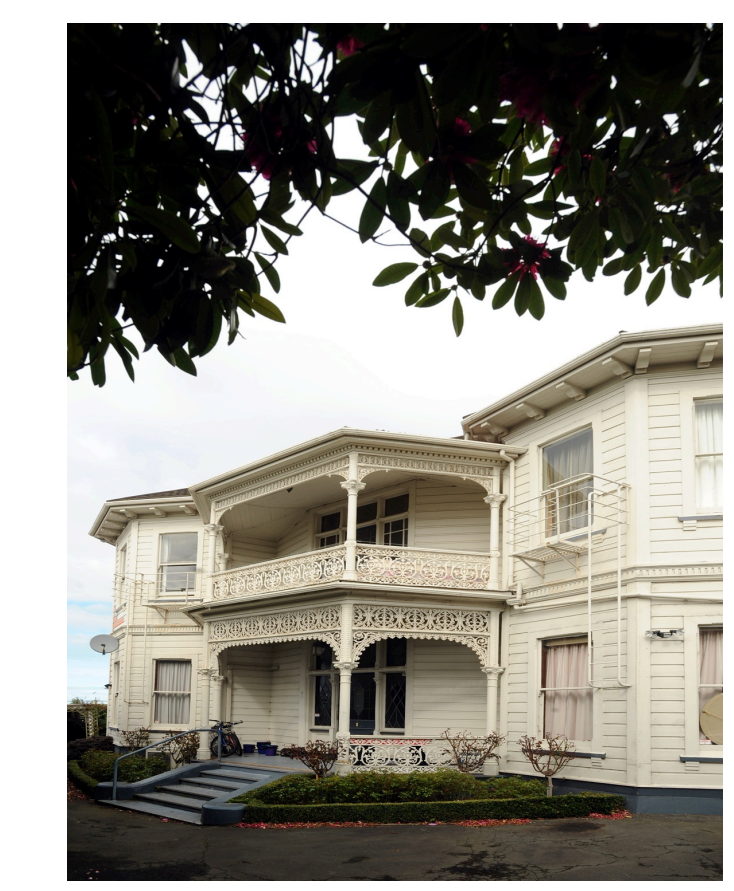

Photo: 1 Royal Tce, Dunedin. Photo: Stephen Jaquiery.

\section{A thesis submitted as partial fulfilment of the requirements of the}

Degree of Masters in Museum and Heritage Studies

By

Imogen Stockwell

Victoria University of Wellington 2016 



\begin{abstract}
Following the 2010 and 2011 Canterbury earthquakes, earthquake strengthening is one of the biggest issues facing heritage buildings in New Zealand. This process is mainly affecting commercial and public buildings; residential buildings are generally exempt from earthquake-prone building policies. However, some homeowners are choosing to do what is often perceived to be an expensive and time-consuming process. This research explores whether there is a heritage relationship between the homeowner and their house that motivates conservation work, such as earthquake strengthening. The central question for this research is: "What makes a heritage house a home? Is "home" a motivation for owners to earthquake strengthen their building? a case study of Dunedin".
\end{abstract}

The relationship between homeowners and the heritage of their homes and domestic conservations practices has been underexamined in heritage studies in New Zealand. The current dissertation addresses this problem and contributes to the literature of Museum and Heritage Studies. The theoretical framework employed in this research draws on the field of Critical Heritage Studies in order to explore the relationship between 'top-down' and 'bottom-up heritage', the notion of 'peoples-based' heritage, the value of intangible heritage and a cycle of care. This research utilised qualitative research methods, involving the interviewing three heritage homeowners and two heritage professionals. These provided detailed findings about homeowners' perceptions of their houses and the interaction between heritage practitioners and homeowners. The southern city of Dunedin was the case study which framed this research, because it has a rich collection of heritage buildings and a council which has been proactive in encouraging earthquake strengthening.

It was found that the heritage homeowner's relationship with their home played a role in conservation how decisions are undertaken and that there is a lack of outreach from heritage authorities to heritage homeowners. This research provides information about the nature of the interaction between top-down and bottom-up heritage, and how this relationship can lead to positive heritage outcomes. Recommendations include developing open channels of communication between officials and homeowners, increased acknowledgement of the homeowner's role in the conservation practice, and the establishment of a concept of Domestic Heritage to assist within the development of a cycle of care by heritage homeowners. 


\section{Acknowledgements}

This dissertation could not have been completed without the support of a number of people. I especially want to thank my supervisors, Conal McCarthy and Moira Smith, who have guided me through this process. Your knowledge, patience and support have been integral to my finishing this piece of work. I would also like to acknowledge the support of the Museum and Heritage Studies staff at Victoria University of Wellington, as well as the support and companionship of my fellow classmates.

My parents, Sue and Peter, and sister, have been rocks over the course of my Masters. Food parcels, phone calls and confidence boosts are only a few of the ways you have supported me. My dad requires special mention for very diligently proof reading this dissertation, I promise not to do one again in a while.

Last, but most certainly not least, thank you to my partner Ben. You have tolerated all the ups and downs, endless questions and late nights, all while completing your own research. Thank you for encouraging and supporting me while I navigated my research, moved around the country and started a new job. 


\section{Contents}

\section{Introduction}

What makes a house a home?

\section{Chapter one}

Background: Earthquakes, domestic architecture and Dunedin

\section{Chapter two}

Interviews with heritage professionals and homeowners:

Views from top-down and bottom-up

Chapter three

Analysis and discussion: It's all about the people

\section{Conclusion:}

Towards a Domestic Heritage

Bibliography

Appendix one:

Questions from the interview with DCC Heritage Planner

\section{Appendix two:}

Questions from the interview with HNZ Area Manager Otago and Southland

Appendix three:

Questions from the interview with Homeowner one

\section{Appendix four:}

Questions from the interview with Homeowner two

Appendix five:

Questions from the interview with Homeowner three 


\section{Introduction:}

\section{What makes a house a home?}

In the wake of the Christchurch earthquakes of September 4, 2010 and February 22, 2011, one of the biggest threats to our heritage buildings is the risk of earthquakes and the associated drive to strengthen or demolish buildings. These earthquakes-in particular the February 22, 2011, 6.2 magnitude quake, which resulted in 185 deaths-prompted the establishment of the Royal Commission of Inquiry into Building Failure Caused by the Canterbury Earthquakes. ${ }^{1}$ This commission presented its findings in the form of a three-part report, in which a number of recommendations were made regarding geotechnics, building performance, minimising risk in pre-existing and future buildings, legislation, policies and building practices. The earthquakes and these recommendations have prompted some councils to implement active earthquake policies and enforce the upgrade of buildings for compliance with building strength codes. The push by authorities to have owners earthquake strengthen or demolish their heritage buildings has forced many to make the decision between spending, what is often perceived to be a huge amount of money on strengthening, or to demolish and start again.

The Canterbury Earthquake Royal Commission reported that buildings which had been retrospectively seismically strengthened were more likely to have survived the earthquakes, suggesting that such strengthening was beneficial. Earthquake-prone building policies stipulate what types of buildings need to be earthquake strengthened. Commercial and public buildings are targeted, and in general residential buildings are exempt from earthquake strengthening requirements, unless they are two or more storeys and have three or more household units. As a result of the requirements on commercial and public buildings, local councils are targeting these building owners with incentives and support for seismic strengthening. However, despite the lack of legal requirement, financial aid and official support, some homeowners are choosing to undertake earthquake-strengthening work on their houses, a number of them are heritage homeowners. It is intended that by exploring why these homeowners undertake this work and how official processes play a role in this decision, insight can be gained into what motivates heritage-building owners to make decisions that

\footnotetext{
${ }^{1}$ Canterbury Earthquakes Royal Commission, Final Report: Volume 1-Summary and Recommendations in Volumes 1-3 Seismicity, Soils and the Seismic Design of Buildings (Christchurch: Canterbury Earthquakes Royal Commission, 2012), 3 .
} 
provide a more stable future for their properties. Critical Heritage Studies provides the theoretical framework for this research because it intends to analysis heritage management. However, little research has been done into what these professional heritage practices are, a gap which this research will be working within. ${ }^{2}$

In order to address the central question of this research-"What makes a heritage house a home: motivations for earthquake strengthening of private dwellings, a case study of Dunedin"-we need to establish three key points: first, is there a heritage relationship between a homeowner and their house, second, does this heritage relationship contribute to how they care for and regard their home, and third, is this relationship a motivating factor for a homeowner to undertake earthquake strengthening? This dissertation aims to reveal motivating factors related to heritage, which influence the decision making process to earthquake strengthen homes, and therefore help secure a building's future for the next generation. This research is especially necessary in a country where seismic activity is a real threat and where the predominance of private property rights mean that councils and heritage agencies have limited influence over what homeowners do to structures on their land. The following review looks at the literature across three broad areas relevant to this topic: critical heritages studies and why it is appropriate for this research, 'peoples-based' heritage in relation to the concept of home, and how risk contributes to the conservation of heritage.

\section{Literature Review}

One key point that students of heritage studies struggle with is understanding what heritage is and coming to terms with the breadth and changing nature of the concept. Heritage has so many forms that strict definitions create more problems than they solve. The Oxford Dictionary defines heritage as:

1. Property that is or may be inherited; an inheritance.

2. Valued objects and qualities such as historic buildings and cultural traditions that have been passed down from previous generations. ${ }^{3}$

\footnotetext{
${ }^{2}$ Critical heritage studies has been used to investigate current heritage practices by the likes of Moira Smith,

" "A Useful Accessory": The use of lightweight replica ornament to manage the cultural heritage values of earthquake-prone buildings" (MA diss., Victoria University of Wellington, 2015).

3 "Heritage", accessed March 12, 2015, http://www.oxforddictionaries.com/definition/english/heritage?q=Heritage.
} 
This definition provides us with a starting point, but as a social concept working in many different ways at all levels of society, a definition must be more fluid and emotive, making allowances for the various uses of heritage nationally, culturally and personally. Iain Robertson outlines the breadth of the concept in his book Heritage from Below: "Heritage is about... people, collectivity and individuals, and about their sense of inheritance from the past and the uses to which this sense of inheritance is put. It is about the possibilities that result from the deployment of the past". ${ }^{4}$ Fundamentally, heritage studies is the critical study of heritage. Historically the discipline has focused on national heritage, but since the 1980s increasing numbers of heritage professionals have acknowledged the importance of community and personal heritage. Practising heritage professionals and heritage policies are greatly influenced by international bodies, charters and policies, such as World Heritage and ICOMOS (International Council on Monuments and Sites). These international organisations have played a major role in dictating what heritage is and how we should look after it. Today the concept of heritage and heritage studies covers a range of things "from large to small, grandiose to humble, 'natural' to constructed",

Scholars argue that heritage "...is that part of the past which we select in the present of contemporary purposes, be they economic, cultural, political or social." ${ }^{\prime 6}$ Laurajane Smith explores the idea of heritage not so much as a 'thing', but as a cultural and social process, which engages with acts of remembering and works to create understanding and engagement with the present. Rodney Harrison considers the importance of preserving and conserving things correctly because of the legacy that this creates.

Another aspect of these practices of heritage is the ways in which we go about conserving things - the choices we make about what to conserve from the past and what to discard... Practices of heritage are customs and habits which, although intangible, inform who we are as collectives, and help to create our collective social memory. We use objects of heritage ... alongside practices of heritage ... to shape our ideas about our past, present and future. ${ }^{7}$

\footnotetext{
${ }^{4}$ Iain Robertson, Heritage from Below (Surrey: Ashgate Publishing Limited, 2014), intro. 1.

${ }^{5}$ Rodney Harrison, Heritage: Critical Approaches (London: Routledge, 2013), 5.

${ }^{6}$ Brian Graham, Gregory John Ashworth and John Tunbridge, "The uses and abuses of heritage", in Heritage, Museums and Galleries: An Introductory Reader ed by Gerard Corsane (Abingdon: Routledge, 2005), 29.

${ }^{7}$ Rodney Harrison, Understanding the politics of heritage (Manchester: Manchester University Press, 2010), intro 9.
} 
Critical heritage studies emerged as a clear theoretical strand within heritage studies in the 1980s. It incorporates aspects of many other disciplines, but primarily focuses on how the past relates to the present. In his book, Heritage: Critical Approaches, Harrison defines Heritage Studies as:

...an area rich with interest, covering research into what we choose to conserve and why, the politics of the past, the processes of heritage management, and the relationship between commemorative acts and public and private memory... ${ }^{8}$

In this text, Harrison quotes David Uzzell to describe the nature of the discipline: "the lovechild of a multitude of relationships between academics in many disciplines, and then nurtured by practitioners and institutions.". 9 As the field of Critical Heritage Studies has gained traction, there has been increased criticism of how the field either follows a 'top-down' or a 'bottom-up' view of heritage. A 'top-down' approach is used to classify and promote particular places by the state to embody regional, national or international values which create 'official' heritage; and a 'bottom-up' approach is the relationship between people, objects, places and memories that forms the basis of unofficial forms of heritage (usually) at the local level. ${ }^{10}$ This dissertation's research will challenge the need to either follow one or the other, by exploring the grey area between 'bottom-up' and 'top-down'.

Laurajane Smith's extensively quoted work Uses of Heritage establishes the concept of AHD (Authorised Heritage Discourse), the existence and dominance of "a certain set of Western elite cultural values as being universally applicable". ${ }^{11}$ Authority and Westerndriven heritage is challenged by bottom-up heritage where local cultural groups practise their own heritage. Harrison criticises critical heritage studies for focusing on either one or the other of these views, stating "...heritage studies as an academic discipline was concerned with the study of two processes [top-down and bottom-up] and the relationship between them." 12 And it is in this area that my research is positioned, exploring the relationships of

\footnotetext{
${ }^{8}$ Harrison, 2013, 8.

${ }^{9}$ Harrison, 2013, 9 .

David Uzzell, "Where is the Discipline in Heritage Studies: A view from environmental psychology", in Heritage Studies: Methods and Approaches, ed by Marie Louise, Stig Sørensen and John Carman, 326-333

(London: Routledge, 2009), 326.

${ }^{10}$ Rodney Harrison, 2010, intro 8.

${ }^{11}$ Laurajane Smith, Uses of Heritage (Abingdon: Routledge, 2006), 11.

${ }^{12}$ Rodney Harrison, "What is Heritage?", in Understanding the politics of heritage, ed. Rodney Harrison (Manchester: Manchester University Press, 2010), 38.
} 
homeowner and home (bottom), local council and heritage (top), and how these two processes work together to preserve built heritage.

Increasing numbers of heritage practitioners and academics are highlighting the universality of heritage. John Schofield emphasises that heritage is everywhere, for everyone, that we are all heritage experts, and pushes for greater acknowledgement of the importance of stakeholder opinion in heritage. ${ }^{13}$ He writes: "These multiple views of heritage, of what matters and why, take us beyond the conventional boundaries of heritage. They take us beyond its comfort zone, from the special and the exceptional places and things, to the everyday." ${ }^{14}$ Schofield is critical of the focus within official heritage on the great and old:

Not only does this deny the existence of modern heritage, of the heritage we ourselves create, but more significantly it serves to disenfranchise whole communities who only value their familiar surroundings; who have no interest in Stonehenge, or other iconic monuments on the World Heritage List, yet they may value the place they were born, or a garden, or a street corner for some memory associated with it. ${ }^{15}$

Schofield's emphasis on unofficial heritage works within 'heritage from below' ideals. Schofield quotes Don Henson “....in our professional attitudes to heritage, we remain disrespectful of the people of the past and instead make a fetish of their structures, unmindful of their memories... this needs to change." ${ }^{\prime 16}$ This need for a shift in the focus of the heritage industry is also discussed by Dean Sully. Sully's 'peoples-based' heritage conservation prioritises community welfare over material-based heritage. Through this approach objects of heritage continue to perform their role within the community, so that old values and meanings are revealed through ongoing interaction. Sully criticises heritage conservation practices for placing too much emphasis on preserving a set of ideas regarding an object and not in understanding the effects that objects have on people. For Sully, conservation of a heritage object needs to reflect the objectives of the associated community. This bottom-up approach places importance on intangible heritage, which enables the consideration of community objectives within heritage practices:

\footnotetext{
${ }^{13}$ John Schofield, "Heritage Expertise and the Everyday: Citizens and Authority in the Twenty-first Century", in Who needs experts? Counter-mapping Cultural Heritage (Surrey: Ashgate publishing Limited, 2014), 1-12.

14 Schofield, 2014, 1.

15 Schofield, 2014, 3.

${ }^{16}$ Schofield, $2014,7$.
} 
The Intangible Heritage Convention has helped to rebalance the focus of heritage professionals from the material authenticity of cultural heritage to the social process of capacity building and provision social benefits for participant communities in the heritage process. ${ }^{17}$

Sully points out that achieving community participation can be challenging for heritage professionals, one solution to this challenge is to expand "the goals of conservation and associated working methods, rather than limiting them". ${ }^{18}$ If heritage professionals can find a way to work with communities on community-led projects the possible benefits could include aiding social welfare and morale. ${ }^{19}$ When applying community-led heritage to domestic architecture, the homeowner represents the community and the house represents the object. Therefore, if we can clarify how heritage homeowners identify and interact with the heritage of their abode, we can establish improved ways for heritage professionals (the council) to work with homeowners to create practices which provide benefits for the homeowner, thus encouraging the retention of heritage.

The phrase 'intangible heritage' was originally constructed to criticise the focus of official heritage management on the heritage fabric or physical object. ${ }^{20}$ It has allowed for heritage professionals to explore non-material aspects of indigenous cultures, and provided heritage management with a theoretical approach for dealing with places that have a cultural significance to indigenous groups.

In addition to these physical objects and places of heritage there are also various practices of heritage that are conserved or handed down from one generation to the next. ... These invisible or 'intangible' practices of heritage, such as language, culture, popular song, literature or dress, are as important in helping us to understand who we

\footnotetext{
${ }^{17}$ Dean Sully, "Conservation Theory and Practice: Materials, Values, and People in Heritage Conservation", in The International Handbook of Museum Studies: Museum Practice, ed Conal McCarthy (John Whiley and Sons 1td, 2015), 307.

${ }^{18}$ Sully, 2015, 307.

${ }^{19}$ Sully, 2015, 308.

${ }^{20}$ Rodney Harrison and Deborah Rose, "Intangible heritage", in Understanding heritage and memory ed Tim Benton (Manchester: Manchester University Press, 2010), 240.
} 
are as the physical objects and buildings that we are more used to thinking of as 'heritage'. 21

Intangible heritage is also closely linked to ideas of community heritage which are most often associated and recognised in international charters and government policy, such as ICOMOS' New Zealand Charter, in relation to indigenous heritage. In New Zealand's case this is predominantly with Māori. '... [I]ntangible heritage comprises not just the "colourful and exotic" cultural performances identified in the UNESCO lists, but the meanings, associations, knowledge, skills, and perceived significance and values that provide context and understanding for tangible heritage." ${ }^{22}$ These are ideas which Alison Wain believes are well established in the theoretical framework for heritage professionals negotiating non-Western and indigenous populations, but not well established for those working with Western cultures. ${ }^{23}$ Rodney Harrison and Deborah Rose believe that Western heritage practitioners have not adopted intangible heritage because they associate it with ideas of gossip and rumour. ${ }^{24}$ However, Wain asks: "How can the understanding of the importance of intangible heritage and stakeholder values be brought into the standard canon of conservation theory and practice in relation to all heritage." 25 This research has the potential to bridge this issue and bring intangible heritage concepts into the mainstream when dealing with both Western and non-Western heritage. This is because the concept of home has both tangible and intangible heritage associations, and is also a universal concept which spans both Western and non-Western cultures.

Smith discusses heritage as a process of true engagement with an object through emotions and a sense of self, "in the act of passing on and receiving memories and knowledge." ${ }^{26}$ The domestic setting is a place where memories are formed and personal knowledge gained. Memories and knowledge "help us make sense of and understand not only who we 'are', but also who we want to be." ${ }^{27}$ This intangible heritage can be linked to tangible heritage.

\footnotetext{
${ }^{21}$ Harrison, 2013, intro 9.

${ }^{22}$ Alison Wain, "Conservation of the intangible: a continuing challenge," in AICCM Bulletin volume 35 (2014): 53.

${ }^{23}$ Wain, 2014, 53.

${ }^{24}$ Harrison and Rose, 2010, 271.

${ }^{25}$ Wain, 2014, 56.

${ }^{26}$ Smith, 2006, intro 2.

${ }^{27}$ Smith, 2006, intro 2.
} 
Schofield discusses people's attachment to places, emphasising the memories and stories individuals connect to buildings, places and landscapes. Schofield argues that "The landscape is full of stories, and stories make memories. It is those memories that create our conceptions of heritage, and which make it inevitable that we attach values to the places that matter to us. ${ }^{28} \mathrm{He}$ adds: “...Connections between people and landscape are strongly expressed through individual stories." 29 The individuality of a home and the personal connection can be seen in the varying ways that people make a house a home. Witold Rybezynski considered the idea of 'home' and in particular discusses the differing ways people make their homes comfortable. Feeling comfortable is a very subjective experience, one that is governed by the statement "I may not know why I like it, but I know what I like". ${ }^{30}$ Lori Mastermaker's research into Duart House in the Hawkes Bay highlighted two points relevant to my research. Firstly, the focus on community is an example of "bottom-up" heritage. Secondly, "how highly complex the heritage process can be between people, place and memory"31. In order to deal with the complexity of individual relationships, especially of a person's relationship to their home, the understanding of some basic concepts relating to the heritage sector need to be addressed.

Central to this is having heritage professionals acknowledge the variety and diversity of personal experience in relation to heritage. Emma Waterton and Steve Watson's book Heritage Community Engagement: Collaboration or Contestation is critical of the way heritage authorities have a tendency to approach community involvement in heritage processes by a 'tick the box' system, tacking community consultation on the end of protocol and a tendency to group smaller minority groups together as the 'community', irrespective of the diversity within the communities. ${ }^{32}$ Waterton and Smith state that one of the reasons for this is that the concept of 'community' has become a buzzword which is incorporated into statements and policy to make people feel good. ${ }^{33}$ However, the reality is that a community is

\footnotetext{
${ }^{28}$ Schofield, 2014, 2.

${ }^{29}$ Schofield, 2014, 4.

${ }^{30}$ Witold Rybezynski, Home: A short history of an idea, (New York: Penguin Books, 1986), 231.

${ }^{31}$ Lori Mastemaker, "Memory, Performance, Identity: Making Personal History, Making Meaning A critical analysis of an independent heritage initiative at Duart House, Havelock North", (MA diss.,Victoria University of Wellington, 2010), 88.

${ }^{32}$ Emma Waterton and Steve Watson "Heritage and Community Engagement: Finding a new agenda", 1-11, in Heritage and Community Engagement: Collaboration or Contestation? ed by Emma Waterton and Steve Watson (Abingdon: Routledge, 2010), 3

${ }^{33}$ Emma Waterton and Laurajane Smith, "The recognition and misrecognition of community heritage", 12-23 in Heritage and Community Engagement: Collaboration or Contestation? ed by Emma Waterton and Steve Watson (Abingdon: Routledge, 2010), 12-15.
} 
a collection of people who often have only one thing in common, therefore any attempt to treat a 'community' by one blanket approach will be misrepresentative, and consequently may alienate people. Lori Mastermaker makes a case in her Masters thesis that "Museums need to understand and take into account that they cannot possibly accommodate the highly personal and multi-layered nature of individual memory and human variability and be 'everything to everybody'." 34 While this approach is appropriate for museums, it is not necessarily appropriate for heritage legislation which deals with individual homeowners. Since councils generally deal with heritage buildings on a case-by-case basis, there need to be mechanisms that accommodate the individual in their legislative process, by acknowledging that one size will not fit all.

One method to deal with individual communities is through community-led projects which rely on the community in question placing importance on the retention of their heritage and heritage objects. Elizabeth Crooke states: "Rarely will a community group participate in heritage without reason: there are often distinct motivations behind such activity that reflect the needs and aspirations of the community." 35 The connection between caring for heritage and the value of heritage is interlinked, as Sully points out: "This highlights the tautology of cultural heritage and conservation; conservation is a cultural process and its actions create heritage, therefore we are for heritage not only because it is valued-it is valued because we care for it." ${ }^{36}$ Finding out why a community places importance on its heritage is crucial to establishing processes that aid the retention of that heritage, this principle translates to personal heritage as well. By identifying what people consider important about their personal heritage and how it relates to their homes, councils can implement processes that highlight this to heritage homeowners and thus a system of care and value can be established.

The system of care and value can begin through the initial recognition of a possible threat to heritage. Harrison comments on the connection between heritage and threat, asserting that many things only become 'heritage' when they are at risk of being lost. ${ }^{37}$ Harrison perceives the risk of losing heritage as a motivational factor for community groups to recognise an

\footnotetext{
${ }^{34}$ Mastemaker, 2010, 90.

${ }^{35}$ Elizabeth Crooke, Museums and Community: ideas, issues and challenges (Abingdon: Routledge, 2007$), 9$.

${ }^{36}$ Sully, 2015, 296

${ }^{37}$ Harrison, 201313.
} 
aspect of their culture, whether it be tangible or intangible, and fight for its survival. ${ }^{38}$ This perceived risk does not need to be an immediate force for parties to take action, it could be a potential threat due to political activity or events elsewhere. ${ }^{39}$ One example of a New Zealand community getting behind their heritage and fighting against commercial and governmental forces was in 2002 when the residents of Hayes Paddock in Hamilton fought to have their state housing estate designated as a heritage area in order to prevent property developers from destroying the unique character of the area with 'town-style' housing. ${ }^{40}$ Steve Watson and Emma Waterton see a link between the growth of the heritage industry and the way public respond to heritage:

The growth of the 'heritage industry' over the last 20 years has also had an effect in motivating and energising individuals and communities to engage with the past in a broader range of activities from watching television programmes to visiting sites as tourists and, not least, through the organisation of community activity. ${ }^{41}$

Hayes Paddock is an excellent example of a community recognising their heritage as a result of a threat and responding to it through legal processes. It exemplifies how people can place importance on humble heritage-such as state homes-taking pride in it and using authoritative measures to preserve it.

Andrea Witcomb looks at how the concept of 'affect' contributes to our understanding of heritage. ${ }^{42}$ She takes the emotional experience visitors have when faced with difficult material and how heritage sites and exhibitions use this emotional experience to change people's understanding rather than relying on information-based methods. This technique of gaining understanding and changing people's stance through emotion is an 'affect' based technique. Witcomb discusses 'affect' in relation to negative material, by looking at the interaction between an active person and an inactive object. This research aims to borrow from Witcomb in its exploration of affect, however the focus will be on positive and negative

\footnotetext{
${ }^{38}$ Harrison, 2013, 20.

${ }^{39}$ Harrison, 2013, 13.

${ }^{40}$ Ben Schrader, We Call it Home: a History of State Housing in New Zealand (Auckland: Reed Publishing, 2005), 238

${ }^{41}$ Waterton and Watson, 2011, 3 .

${ }^{42}$ Andrea Witcomb, "Understanding the role of affect in producing a critical pedagogy for history museums", in Museum Management and Curatorship 29, 3 (2013): 255-271.
} 
interactions that people have as they live in their homes and how these interactions are experiences that generate feelings.

An issue with researching such a personal connection is using the appropriate approach that will reveal the required information, but is not too formal. Witcomb provides a solution to this issue in her exploration of Walter Benjamin's text, Illuminations:

Thinking, as Benjamin points out..., requires not only the flow of thoughts but their arrest as well. In that arrest is the hope of a different future. The big question is whether everyone is prepared to seize this moment and work with it. Only deep ethnographic analysis of audience responses across the political spectrum, ethnic and racial differences as well as different levels of education would tells [sic] whether or not these interpretative strategies can hope to achieve the kind of alteration to the self that Ross Gibson (2004) is after. ${ }^{43}$

This approach to studying an exhibition's influence on a visitor can also be used to approach the heritage relationship between a person and their home. This literature review demonstrates that a homeowner's heritage relationship with their house has not been extensively explored in academic research. This neglect reflects a number of factors: common domestic architecture is not glamorous, the heritage relationship is exceptionally personal and diverse within single social groups and across cultures, and practical issues with influencing the preservation of domestic dwellings due to private property rights. The concept of 'home' implies that a special relationship exists:

After all, 'home' has much more resonance than 'house,' rich as it is with associations of family and belonging. ... In fact, we tacitly accept the notion that a house is simply a building while a home is a domestic setting, filled with human meanings, whose spaces reflect the endless subtleties of everyday family life. ${ }^{44}$

This heritage relationship is based on a personal connection where the building evokes memories of the past for the occupant in the present.

\footnotetext{
${ }^{43}$ Whitcomb, 2013, 269.

${ }^{44}$ Peter Ward, A History of Domestic Space: Privacy and the Canadian Home (Toronto: UBC Press, 1999), 3.
} 
The relationship between the house and the lives it enfolds is complex. Now-as in the past-we choose, build, or alter our dwellings in order to meet some of our needs beyond the basic one of shelter. In turn, because our homes are physical spaces, they impose constraints on us just as they create opportunities for us. In a sense the home is the theatre of our domestic experience, the stage on which we can enact much of the long drama of our lives. ${ }^{45}$

Consider Don Henson's statement: "The key aspect of heritage is not what it is, a custom or an object, but the relationship that exists between people in the present and activities of people in the past that custom of object represents." ${ }^{, 46}$ Henson is emphasising that heritage is the relationship, which is preserved by the homeowner through their memories and daily rituals. Rachael Kiddey discusses what makes a dwelling a home, evoking ideas and concepts of warmth, privacy, food, feeling welcome, safe place, combating loneliness, company. ${ }^{47}$ Since her research focused on the homeless these concepts regard a non-conventional home and were related to the physical structure, as well as the experiences her interviewee had in their shelter. Kiddey's research emphasises the various physical forms a home can take while still retaining the sense of a home. Heritage is not just the physical site, it is also what goes on at these sites that constitute the cultural heritage performance. ${ }^{48}$

A threat to heritage homes in New Zealand is earthquake, and this threat has led some homeowners to take action-either strengthening their homes, or demolishing and starting again. The literature considered above has examined the existence of a heritage relationship between a homeowner and their house and how this relationship plays a role in the decision to pursue preservation. What is left to consider is whether this relationship motivates the homeowner's decision to undertake earthquake strengthening. Currently little has been written on the topic of motivations for earthquake strengthening, and even less on residential buildings. Egbelakin and Wilkinson have examined factors motivating building owners to seismic strengthen their commercial premises. ${ }^{49}$ Their research identified economic factors,

\footnotetext{
${ }^{45}$ Ward, 1999, 6.

${ }^{46}$ Don Henson, "Finding People in the Heritage of Bankside, Southwark", in Who needs Experts? Countermapping Cultural Heritage ed. John Schofield (Surrey: Ashgate Publishing Limited, 2014), 147.

${ }^{47}$ Rachael Kiddey, "Punks and Drunks: Counter-mapping Homelessness in Bristol and York", in Who needs Experts? Counter-mapping Cultural Heritage ed. John Schofield (Surrey: Ashgate Publishing Limited, 2014), 172.

${ }^{48}$ Mastemaker, 2010, 86.

${ }^{49}$ Temitope Egbelakin and Suzanne Wilkinson, "Factors Affecting Motivation for Improving Seismic Retrofit Implementation," Australian Earthquake Engineering Conference AFES November 2008.
} 
social factors and regulatory requirements as motivational factors prompting building owners into achieving higher seismic strengthening.

Egbelakin and Wilkinson consider motivational factors as crucial to the decision making process, and by understanding these motivations we can aid building owners in the process of heritage protection and earthquake strengthening. What they do not examine in their paper is whether building owners have a connection with their buildings, and if this connection is a motivational factor for seismic retrofitting. Unlike commercial property owners, homeowners generally have no regulatory requirement to complete earthquake strengthening. Therefore most seismic work completed on domestic dwellings is done out of the owner's free will. Economic and social factors do undoubtedly play a role, but to what extent does a person's connection with their home contribute to the decision making process? As the literature reviewed above has outlined, homeowners represent a community with whom the authorities must negotiate to achieve mutually beneficial outcomes. Therefore, it is worth considering what motivates communities to undertake action or actively participate in a community heritage project. Crooke states that a common motivation in the Northern Ireland Community History Programme was the idea of change or transformation, ranging from grander notions of greater social cohesion to more humble notions of personal discovery. ${ }^{50}$

New Zealanders are culturally trained to place great importance on buying and owning their own home; in fact, buying your first home is considered a life goal which many strive for. At Home in New Zealand: History, Houses, People, edited by Barbara Brookes, focuses on the domestic realm, and highlights the need to explore New Zealand homes in more detail. Despite the broad nature of New Zealand's love affair with homeownership and love of picturesque buildings, little has been written on New Zealanders' relationship with their homes. Several writers have hinted at the importance of domestic architecture to our built historic heritage. Ian Lochhead claims the prominence of Gothic architectural styles in our architecture is important to New Zealanders "Because of its capacity to remind us of pasts that are distant, disparate and even mythical, it has become an essential part of our concept of home. ${ }^{, 51}$ Furthermore, David Kernohan states:

\footnotetext{
${ }^{50}$ Crooke, 2007, 9.

${ }^{51}$ Ian Lochhead, "At Home with the Past: The Gothic Revival House in New Zealand", in At Home in New Zealand: History, Houses, People, ed. Barbara Brookes (Wellington: Bridget Williams Books, 2000), 23.
} 
The best of New Zealand's architecture is displayed in its domestic buildings. The handsome villas of the Victorian and Edwardian eras still provide fine homes for many inner city dwellers. ... The individual house on its 'quarter acre section' became not just a physical aspiration but also an expression of the quality of life in New Zealand. ${ }^{52}$

Both authors are speaking of the relationship New Zealanders have with their heritage homes in reference to their architectural style and how it evokes ideas of national heritage, placing emphasis on the aesthetic value and top-down heritage values. Neither of these texts how we associate with the heritage of our homes, and how this plays a role in our decision to give such structures stable futures, which is the aim of my research.

Only moderate research has been published examining the relationship between heritage homeowners and their houses, and the role this relationship plays in motivating people to undertake earthquake strengthening in New Zealand. The earthquake strengthening of buildings around New Zealand is a topical issue due to the recent Canterbury earthquakes, confirming the need for work to be done in this area. The lack of academic literature relating to the impact this process has on heritage buildings highlights the need for research in the area. The field of critical heritage studies allows this research to investigate a 'peoples-based' heritage, examining a practice of community-led heritage conservation. This would empower homeowners to create stable futures for their homes through earthquake strengthening aided by official heritage organisations. In this case the earthquakes are the threat, the physical house is the tangible heritage and the personal connection and memories associated with home are the intangible heritage elements. Research into the extent to which heritage relationships play a role in motivating people, could allow local councils to incorporate these heritage values into official heritage practice, thereby encouraging homeowners to choose earthquake strengthening.

\section{Methodology}

At a fundamental level this research aims to explore the relationship between homeowners and their heritage home. In order to achieve this it was necessary to investigate how a person

\footnotetext{
${ }^{52}$ David Kernohan, Wellington's New Buildings (Wellington: Victoria University Press, 1989), intro 1.
} 
perceives their property, what they value about it, and whether the heritage label attached to their building influences their decision to ensure the survival of the structure. A qualitative approach was deemed appropriate for finding out this information. Through this methodological approach we can answer the research question-"What makes a heritage house a home: motivations for earthquake strengthening of private dwellings, a case study of Dunedin".

This research aims to discover a personal connection between people and their heritage homes. Although this requires an appropriate academic approach, following research conventions and practices, the process of data collection must not be so formal that it alienates participants. Andrea Witcomb references Water Benjamin in relation to the study of 'affect' in museums and suggests ethnography as an approach. It seems reasonable to assume that studying an exhibition's influence on a visitor can also be used to approach the heritage relationship between a person and their home. Therefore, for the purposes of this dissertation I have utilised ethnographic research methods, which will enable the exploration of homeowners' connection to the built environment of their daily personal life through one-onone interviews. ${ }^{53}$

Qualitative methods are most suited to exploratory and ethnological research and research which aims to investigate human reactions and participants points of view. ${ }^{54}$ Through this approach I was able to ask in-depth questions, focusing on fewer but more detailed cases. Qualitative methodology allows for the use of a number of approaches to gathering data, utilising various sources relevant to the topic and thus creating a more detailed picture than a wider less in-depth process. My research has been defined by a case study, and uses interviews and general policy analysis, to answer the research questions.

Case studies are a common element of heritage-based research. An example is David Harvey who states his reasoning in his chapter in Critical Heritage:

The practice of engaging with these case studies through recourse to heritage concepts will help us to understand heritage as a process, or a verb, related to human action and

\footnotetext{
${ }^{53}$ Karen O'Reilly, Key concepts in Ethnography (London: Sage Publications, 2009), intro. 3.

${ }^{54}$ Martyn Denscombe, The Good Research Guide: For small-scale social research projects (Maidenhead: Open University Press, 2010), 110.
} 
agency, and as an instrument of cultural power in whatever period of time one chooses to examine. ${ }^{55}$

Martyn Denscombe states that case studies enable us to "understand the complex relationship between factors as they operate within a particular social setting" ${ }^{56}$ Case studies are used by researchers to gain an in-depth understanding of relationships, experiences and processes occurring in a specific instance. The aim of this research is to investigate the relationship of people to their homes and to examine their experiences with and attitudes towards the process of earthquake strengthening; these aspects are not only linked to one another, but are also interlinked with a number of other aspects within the social setting. ${ }^{57}$ Graham Thomas highlights that case study research methods have been criticised for attempting to apply specified information to general situations. His text, "The Case: generalisation, theory and phronesis is case study," states that instead of using the knowledge generally, it can be seen as exemplary knowledge, and that the research structure and question needs to allow for the context of the case study. ${ }^{58}$

As the primary question outlines, Dunedin will be the case study for this research. Dunedin has been chosen for a number of reasons. First, Dunedin's growth period during the Gold Rush has meant that the city has a rich collection of New Zealand Victorian and Edwardian architecture. Second, the nature of Dunedin as a university town means that many buildings have been the subject of historical research. Third, I have a personal connection to Dunedin and a large amount of my past research has been based on themes relevant to Dunedin's history and as a result I am knowledgeable on the social, economic and political history of the area. And fourth, in May 2015 the national government announced a revision to the time period for owners of earthquake prone buildings to be fixed. Dunedin was rated 'low risk' for earthquakes, as a result property owners of earthquake prone buildings will have 35 years to demolish or fix their buildings. ${ }^{59}$ This extended time period will take the pressure off

\footnotetext{
${ }^{55}$ David C Harvey, "Heritage Pasts and Heritage Presents: Temporality, Meaning and the Scope of Heritage Studies," in Cultural Heritage: Critical Concepts in Media and Cultural Studies, ed by Laurajane Smith (London: Routledge, 2007), 31.

${ }^{56}$ Denscombe, $2010,5$.

${ }^{57}$ Denscombe, 2010, 53.

${ }^{58}$ Graham Thomas, "The Case: generalisation, theory and phronesis of case study", in Oxford Review of Education, vol 37, no 1 (2011): 31.

${ }^{59}$ Otago Daily Times, "New earthquake rules positive for Dunedin", May 11, 2015, http://www.odt.co.nz/news/dunedin/341764/new-earthquake-rules-positive-dunedin
} 
property owners, and change the momentum behind earthquake strengthening in the region. These factors make Dunedin a useful and interesting case study.

An essential part of the research design was conducting interviews with heritage professionals working in Dunedin. Interviews facilitate the gathering of information about people's opinions, feelings, emotions and experiences about sensitive issues and often lend themselves to gaining privileged information. ${ }^{60}$ Interviewing one-on-one enables the researcher to ask in-depth questions specifically tailored to the interviewee. Interviews can take many forms, including: structured, semi-structured, unstructured, one-on-one, group, focus groups and internet. For the purposes of this research the interviews took a semistructured format, meaning that the interviewer had a list of issues and questions to address, but allowed for flexibility to go beyond the questions and for the interviewee to elaborate where appropriate.

The interviews for this research were conducted in October and November of 2015. Due to logistical issues, the interviews were conducted over the phone and recorded using digital recording software. Each interview was transcribed within a week of completing the respective interview. The two professionals interviewed were the Heritage New Zealand Pouhere Taonga (HNZ) Area Manager of Otago and Southland, and the Dunedin City Council (DCC) Heritage Policy Planner. In order to comply with ethics approval these interviewees are identified by their professional title and not their names. The interview questions for the two professionals were designed to gather data on the official position of the organisations they represent regarding earthquake strengthening domestic architecture, and to uncover the strategies each organisation has to conserve and protect the heritage values associated with these buildings. Both professional interviewees were provided with a copy of the interview transcripts to approve. Three heritage homeowners were interviewed by phone, and the interviews were recorded and then transcribed, they were provided the opportunity to see their transcribed interview, but all declined. The primary researcher was the interviewer and transcriber.

The interviewees were found as the result of a snowball effect, meaning they were found through people known to the researcher. In compliance with ethics approval, these

\footnotetext{
${ }^{60}$ Denscombe, 2010, 174.
} 
homeowners are not identified by their names or house locations; they are referred to as "Homeowner one", "Homeowner two", and "Homeowner three". This numerical allocation refers to the order in which they were interviewed. All three interviews followed the same outline, they were asked about official heritage, then personal heritage, and then earthquake strengthening. The questions were tailored for each interview to take into account the heritage status of their homes; this only impacted the official heritage section of the interview.

Depending on your interpretation of 'heritage', all homes could be considered 'heritage homes', however for the purposes of this dissertation the term needs to be defined. For the purposes of this research there are several ways for a house to be considered a 'heritage home'. One way is for it to be on the New Zealand Heritage List, managed by HNZ. This can be listed as either a Category One or a Category Two heritage listed building. A second way is for it to be listed on the local or district council plan, and protected by this. Due to the nature of heritage, an object does not need to be officially identified as heritage to possess heritage value. Therefore, the third way for a house to be classified as a 'heritage home' was if the homeowner, or the person who referred them, considered the building to be heritage. A prerequisite for inclusion in this research was that the interviewees had undertaken earthquake-strengthening work on their homes, this alone means that the houses will generally be older than 1976 when seismic design codes came into place. ${ }^{61}$

The data was processed according to the two interview groups, and coded in line with the format that the interviews took. The primary reason for coding was to organise the data into categories allowing for comparable analysis. ${ }^{62}$ Each interviewee's responses were first organised by question. Then these answers were pulled into themes that had arisen from their answers. These themes were what dictated the flow of the findings chapter and inevitably the direction that this thesis took. The official interviews were processed by method of comparison, outlining what each authority is doing. The homeowner's interviews were processed in a collaborative manner. Finding similarities and themes within their answers and how these related to the research.

\footnotetext{
${ }^{61}$ Canterbury Earthquake Royal Commission, Final Report: Volume 2-The Performance of Christchurch CBD Buildings (Christchurch: Canterbury Earthquakes Royal Commission, August 2012), 5.

${ }^{62}$ N Gilbert, Researching Social Life (Los Angeles: Sage, 2008), 325.
} 
Throughout this research reflexive ideology has been employed, this was particularly important while conducting interviews because of the personal nature of the method. Reflexivity enables the researcher to identify their personal bias within the research process, $\mathrm{J}$ Elliot states that reflexivity provides an approach to qualitative research that takes into consideration subject and researcher experiences and how this influences data collected and processing approaches. ${ }^{63}$ As the sole person undertaking this research and the sole interviewer, it was imperative that I was aware of my role in the research process and to minimise researcher impact I implemented best practice interviewing techniques as outlined by Martyn Denscombe in his text The Good Research Guide.

As in all research, there have been limitations to this research project. The limitations of this research were defined by the length of time allowed for the research, the resources available and the word limit of this dissertation. I only had 12 months to conduct and write-up this research, where time allocation was only part time due to other requirements of this Masters course. Additionally, I was the only researcher, interviewer and transcriber, meaning that the territory explorable was severely limited. Due these limitations boundaries had to be imposed, and the case study was used to assist this process. The number of interviews conducted was one area where caution was required, it was decided that it would be better to do fewer indepth interviews, with the focus on the quality of the material gathered rather than the quantity. With more resources I would have conducted face to face interviews in the heritage homeowners' homes and had these homeowners take me on a tour of their homes, recording their reactions throughout. If there had been more time I would have increased the number of interviewed homeowners who had done earthquake strengthening as well as interviewing homeowners who had considered undertaking work but then decided against it. Additionally, I would have interviewed a greater range of heritage practitioners, including heritage consultants. A more thorough study would provide more data to substantiate claims. Increasing the number and scope of interviewees is an area where further research would be valuable, as well as research of a similar nature in other centres around New Zealand to provide comparison points.

This study is based in critical heritage studies, and used qualitative research methods to explore an ethnological approach to studying heritage homeowners from the case study of

${ }^{63}$ J Elliot, Using Narrative in Social Research (London: Sage Publications Limited, 2005), 154. 
Dunedin. This approach is designed to enable in-depth consideration of the heritage relationship that a homeowner has with the heritage of their home, and whether this relationship was a motivation to undertake earthquake strengthening on their home. The policy analysis and interviews with officials will provide information to consider the interaction between the afore-mentioned heritage relationship and official heritage processes. Practically the resulting conclusions from this research will be most useful to the case study, but should also be informative to local authorities around New Zealand. Academically, any conclusions which can be drawn regarding heritage building conservation motivations is useful, because, as shown in the literature review, this is an under-theorised and underresearched topic within heritage studies.

This dissertation is structured in three chapters. Chapter one sets the scene for this research, providing the context of the 2010 and 2011 Canterbury earthquakes, earthquake-prone building legislation changes and the context of heritage protection in Dunedin. Chapter two presents the findings from the qualitative interviews, this chapter is broken into two sections, the first section examines the findings from the interviews with the heritage professionals and the second section examines the findings from the interviews with the three heritage homeowners. The third and final chapter analyses the findings, placing them in the context of Critical Heritage Studies and of heritage protection in New Zealand and Dunedin, this chapter also analyses the relationship and levels of interaction between top down and bottom up heritage within the Dunedin context. The recommendations that have arisen from this research are outlined in the conclusion. 


\section{Chapter One \\ Background: \\ Earthquakes, domestic architecture and Dunedin}

No research has been published examining the relationship between heritage homeowners and their houses, and the role this relationship plays in motivating people to undertake earthquake strengthening in New Zealand. The literature review demonstrates a lack of academic literature relating to the impact this process is having on heritage buildings highlights the need for extensive research in the area. From the literature review it is clear that the field of critical heritage studies will allow this research to investigate a "peoplesbased' heritage, examining a practice of community led heritage conservation. By researching the extent to which heritage relationships play a role in motivating people, local councils can incorporate these heritage values into their procedures, encouraging homeowners to choose earthquake strengthening over demolition and neglect. This chapter sets the scene for this research, it provides the background information about the Canterbury earthquakes, identifies policies relevant to earthquake-prone buildings and describes official processes around heritage protection. This chapter also places this research in the Dunedin context, detailing DCC policies that impact heritage management in the city.

\section{Canterbury Earthquakes}

In the wake of the Canterbury earthquakes of September 4, 2010 and February 22, 2011, one of the biggest threats to our heritage buildings is the risk of earthquakes and the associated drive to strengthen or demolish buildings. Prior to the Canterbury earthquakes councils could develop and implement their own earthquake-prone building policies as part of duties imposed on them by the Building Act 2004. The legacy of the 2010 and 2011 earthquakes is the Buildings (Earthquake-prone Buildings) Bill 2013 that is currently being considered by parliament, and is intended to amend the Building Act 2004 to regularize earthquake-prone buildings policies nationwide. In light of the bill currently before parliament, many councils have revised their own earthquake-prone policies and moved to active policies which enforce the upgrade of buildings for compliance with building strength codes according to the 2004 Building Act. 
These earthquakes significantly changed the cityscape of Christchurch, the earthquakes themselves and subsequent demolition of earthquake-prone buildings have resulted in the loss of a huge number of heritage buildings in and around the city. ${ }^{1}$ The push by authorities to have owners earthquake strengthen their heritage buildings has forced many to make the decision between an investment in earthquake strengthening, or to demolish and start again. There is also an historic precedence for concern regarding the loss of heritage buildings as a result of legislation and local government initiatives; the 1960s-1980s saw the loss of a large number of old Edwardian and Victorian buildings in Wellington all in the name of progress. From the 1960s increased urbanisation, government expansion and a Wellington City Council push for earthquake strengthening, through upgrades or rebuild, led to the alteration or demolition of distinguished buildings in the city centre, this was particularly notable in the 1980s. ${ }^{2}$ This is a situation which heritage planners and professionals around New Zealand do not want to see repeated.

Heritage Buildings have been put in the spotlight since the Christchurch earthquakes, because of concerns raised about the safety of older, pre-1970s buildings and their performance in earthquakes. Additionally, a number of the buildings listed as earthquake-prone after these earthquakes were heritage-listed buildings. The Canterbury Royal Commission were interested in how heritage buildings which had been earthquake strengthened performed in the Canterbury earthquakes, as a result they requested the New Zealand Historic Places Trust-now Heritage New Zealand-to provide a report. ${ }^{3}$ This report looked at 100 buildings (roughly $10 \%$ of the listed heritage buildings in Christchurch), the majority of which were in Christchurch's CBD, and were listed on the Christchurch City Plan and Banks Peninsula District Plan. The report found that the survival of a heritage building in an earthquake was determined by a number of factors: the type of earthquake, the geotechnics of the ground conditions, the type of construction-unreinforced masonry, timber-framed or other type-and the extent and type of earthquake strengthening that had been undertaken. ${ }^{4}$ The conclusions from this report suggest that building survival during the Canterbury earthquakes was

\footnotetext{
${ }^{1}$ Robert McClean, Heritage Buildings, Earthquake Strengthening and Damage: The Canterbury Earthquakes September 2010-January 2012 (Wellington: Historic Places Trust New Zealand Pouhere Taonga, 2012), 17. 2 Julia Gatley and Paul Walker, Vertical living: the Architectural Centre and Remaking of Wellington (Auckland: Auckland University Press, 2014), 111.

3 "More large shakes occurred on 2 January $2012\left(\mathrm{M}_{\mathrm{W}} 6.0\right)$ with a series of aftershocks taking place up to 15 January 2012." McClean, 2012, 13

${ }^{4}$ McClean, 2012, 8.
} 
enhanced by: "buildings that are timber-framed, steel or reinforced concrete" and "Unreinforced masonry buildings (URM) that had been strengthened". 5 The report also found that "heritage buildings that were severely damaged or destroyed were largely URM that had not been strengthened, partially strengthened or where strengthening was limited to bracing and ties". 6 Incentives were found to contribute positively to the extent of strengthening work that had been completed: "Incentives and grants provided by central and local government made a difference to support earthquake strengthening of heritage buildings". The report found that the majority of strengthening work on buildings that only sustained minimal damage had aimed to be $67 \%$ NBS (New Building Standard) and that much of this work was supported by grants and incentives from public funds. ${ }^{7}$

\section{Heritage Protection in New Zealand}

There are layers of heritage protection in New Zealand all of which are guided by the recommendations of international organisations such as ICOMOS and UNESCO. In New Zealand there are two levels of authority whose role it is to officially recognise and categorise built heritage-Heritage New Zealand Pouhere Taounga (HNZ) and local councils. HNZ is an autonomous Crown Entity, funded through the Ministry for Culture and Heritage and the Heritage New Zealand Pouhere Taonga Act 2014 prescribes its role. Most protective mechanisms for historic heritage are administered by local authorities, although HNZ has regulatory responsibilities for archaeological sites. ${ }^{8}$ The New Zealand Heritage list is managed by $H N Z$ and it "identifies New Zealand's significant and valued historical and cultural heritage places". ${ }^{9}$ This list has two categories: Category One: "historic places are of special or outstanding historical or cultural significance or value"; Category Two: "historic places are of historical or cultural significance or value". ${ }^{10}$ Local authorities are required to work within the Resource Management Act 1993 which makes provisions for the protection of historic heritage within their District Plans. As a result local authorities maintain their own heritage lists. In the case of Dunedin, the DCC manages its own Heritage Register-“The Townscape and Heritage Buildings and Structures Schedule includes buildings and structures

\footnotetext{
${ }^{5}$ McClean, 2012, 8.

${ }^{6}$ McClean, 2012, 8 .

${ }^{7}$ McClean, 2012, 8 .

8 "Introduction to Heritage New Zealand," accessed February 8, 2016, http://www.heritage.org.nz/aboutus/introduction.

9 "About the List", accessed October 31, 2015, http://www.heritage.org.nz/the-list/about-the-list.

10 "About the List"
} 
protected for the contribution their individual heritage value makes to the character of the City's townscape." 11 Protected structures can be listed by a number of ways, for example the DCC has three avenues for a building to become listed: by being listed on the New Zealand Heritage Register by HNZ, through heritage precincts, or by nomination (this can either be by the owner or another party).

\section{Legislative Definitions}

It is worth outlining what is meant by 'earthquake-prone building'. Current legislation regarding earthquake-prone buildings comes from the 2004 Building Act under section 122.

A building is earthquake prone for the purposes of this Act if, having regard to its condition and to the ground on which it is built, and because of its construction, the building-

a. Will have its ultimate capacity exceeded in a moderate earthquake (as defined in the regulations); and

b. Would be likely to collapse causing-

i. Injury or death to persons in the building or to persons on any other property; or

ii. Damage to any other property.

(1) Subsection (1) does not apply to a building that is used wholly or mainly for residential purposes unless the building-

a. Comprises 2 or more storeys; and

b. Contains 3 or more household units.

Note: "ultimate capacity" means seismic load capacity. ${ }^{12}$

This is the definition of earthquake-prone building that all councils around New Zealand follow. The DCC states that "As a general guide, an earthquake-prone building will have a strength that is one-third or less than that required for new buildings by the design standard NZS1 170.5:2004."13

\footnotetext{
11 "Heritage Register", accessed 31 October, 2015, http://www.dunedin.govt.nz/council-online/heritage-register.

${ }^{12}$ Dunedin City Council, Earthquake-prone building policy (including provisions for Dangerous and Insanitary Buildings) (Dunedin: Dunedin City Council, 2012) http://www.dunedin.govt.nz/ data/assets/pdf file/0020/155153/Earthquake-Policy.pdf, 3.

${ }^{13}$ Dunedin City Council, Earthquake-prone Building Policy, 3.
} 
Essential to this research is understanding what constitutes 'earthquake strengthening'. The following information is from the afore-mentioned HNZ report to the Canterbury Royal Commission on the performance of earthquake strengthened heritage buildings.

Earthquake strengthening aims to improve the structural performance of a building. There is a range of methods to improve the structural performance of existing buildings, including heritage buildings. The NZ Society of Earthquake Engineering provides a summary of methods in the guide Assessment and Improvement of the Structural Performance of Buildings in Earthquakes, June 2006. For URM and unreinforced concrete buildings, these methods include: In-plane strengthening-i.e. concrete shear walls and wall facings, concrete frames, braced steel frames, infilling wall openings, plywood faced shear walls; Face-load strengthening-i.e. Floor, roof and ceiling level ties, rosehead washers, mullion supports, parapet bracing, cantilever columns, composite fibre flexural strips, buttressing or propping, helical steel through ties, concrete overlay walls; Combined face-load and in-plane strengthening-i.e. vertical and/or horizontial [sic] post tensioning, deep drilling and reinforcing of walls, grouting rubble filled walls, concrete overlay walls; Diaphragm strengthening-i.e. plywood overlay diaphragms, boundary connections, chords, drag ties, steel flat overlays, concrete topping overlays, roof and ceiling diaphragms; Chimney, towers and appendages-i.e. securing chimney and towers to diaphragms and/or walls, wire tying. In addition, unnecessary seismic mass can be removed such as roof mounted concrete tanks, chimneys and parapets. ${ }^{14}$

This highlights how the term "earthquake strengthening" incorporates a huge range of procedures and types of work.

Early drafts of the Buildings (Earthquake-prone Buildings) Bill 2013 (noted previously) proposed that all potentially earthquake-prone buildings should be assessed within 5 years and strengthened (or demolished) within 15 years. This was amended in May 2015 when parliament released revised guidelines regarding the rules around earthquake strengthening buildings. The current (2015) revision of the 2013 Bill propose the division of the country into three risk zones as shown in Figure 1.

\footnotetext{
${ }^{14}$ McClean, 2012, 34.
} 


\section{NEW RISK ZONES FOR STRENGTHENING}

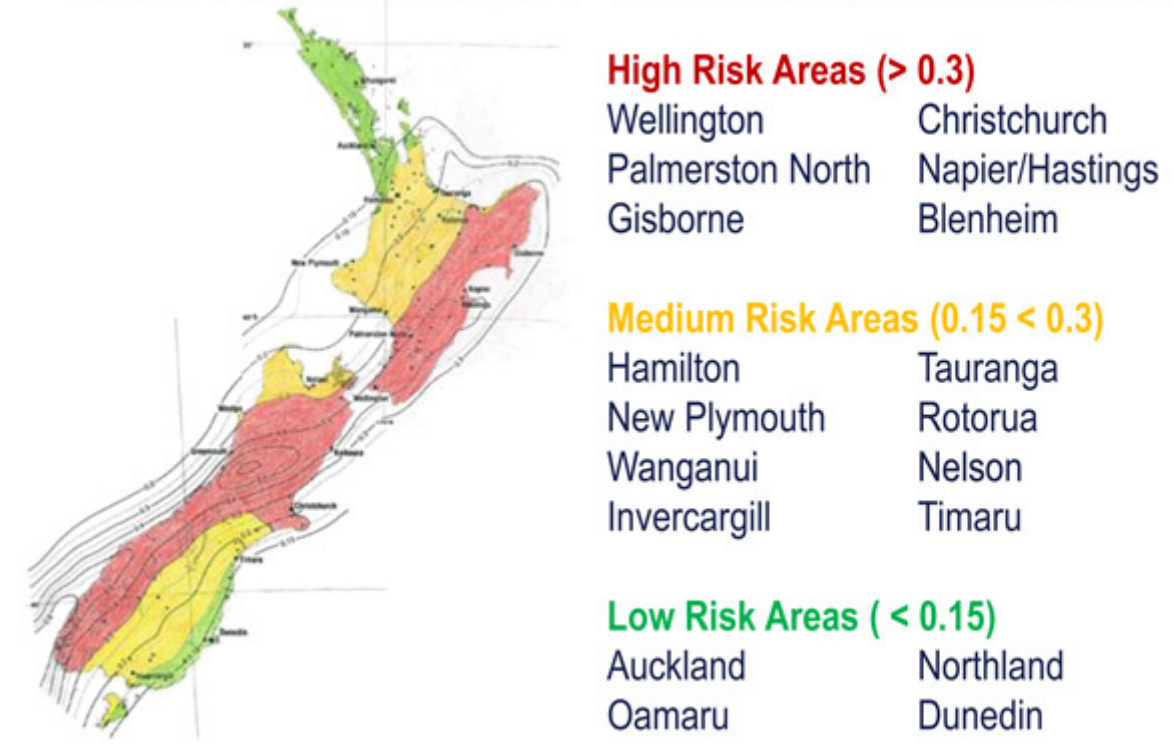

Figure 1: New Zealand Risk Zones for strengthening. Source: beehive.govt.nz, May 2015.

These zones will have different timeframes for assessment and strengthening. Areas of low risk, including Auckland, Oamaru and Dunedin, will have 15 years to undertake building assessments and 35 years to complete strengthening work. Medium and high risk areas have shorter timeframes for both assessment and strengthening. The current Building and Housing Minister Dr Nick Smith "said the changes would reduce the number of buildings that would require assessment from an estimated 500,000 to 30,000, and bring down the total estimated cost from $\$ 1360$ million to $\$ 777$ million." 15 These proposed changes were well received by local and district councils. It is thought likely that further changes to the guidelines shaping earthquake prone building policies will be released by the government, however, exactly what these will be is still unknown. ${ }^{16}$ This proposal was welcomed by the DCC, with Dunedin Mayor Dave Cull stating that the changes were 'positive' for Dunedin. ${ }^{17}$ The feeling had been that previous guidelines were a 'one size fits all' approach to a regionally diverse issue, and that these changes reflected the true status of Dunedin as low risk. ${ }^{18}$ The Mayor stated that the large number of older buildings in the lower South Island "would have been uneconomic to fix [earthquake-proof] them and a lot would have had to be demolished". ${ }^{19}$

\footnotetext{
15 "Big changes to earthquake strengthening rules", New Zealand Herald, May 10, 2015

${ }^{16}$ DCC Heritage planner, "Research Interview," interview by Imogen Stockwell, October 23, 2015.

17 "New earthquake rules 'positive for Dunedin',", Otago Daily Times, May 11, 2015.

18 "New earthquake rules 'positive for Dunedin',".

19 "New earthquake rules 'positive for Dunedin'"
} 


\section{Case Study: Dunedin}

Dunedin is a small city in the South Island of New Zealand with the population of $120,249^{20}$ and is known for its high number of Victorian and Edwardian buildings.

Dunedin is the best-preserved city in New Zealand, where the traditional buildings and colonial open spaces still dominate... The old buildings have rich colours, some picking out the detail, others sweeping across the facades to create a bold geometry. ${ }^{21}$

It is an ideal case study for this research, because a large amount of the built historic heritage falls under the umbrella of domestic architecture. Projects like the Warehouse Precinct on Vogel Street show that the DCC is interested in preserving its architecture. Alexander Trapeznik has produced the most recent work on built heritage in the city. Dunedin's Warehouse Precinct focuses on the new heritage warehouse precinct. He claims that the new interest in this heritage area is in part a reflection of the impact that Christchurch earthquakes have had on our view of building preservation. Implying that the destruction of Christchurch's built heritage has highlighted the risk to Dunedin's buildings and has prompted renewed appreciation for the value of heritage.

The destruction and damage to iconic Christchurch buildings, potent symbols of that city's history-including the Provincial Council buildings, the former university and both cathedrals - has prompted a number of other regional cities to re-evaluate their own heritage buildings. ${ }^{22}$

Trapeznik's work provides an architectural, social and industrial history of a selection of buildings, but does not focus on the heritage of the area and buildings, and their place in Dunedin today, limiting its applicability to current critical heritage studies practice.

Many local councils in New Zealand have decided to delay reviewing their earthquake policies until the national government releases the final version of the Building (Earthquake-

\footnotetext{
20 "2013 Census QuickStats about a place: Dunedin City," accessed January 14, 2016 http://www.stats.govt.nz/Census/2013-census/profile-and-summary-reports/quickstats-about-aplace.aspx? request_value $=15022 \&$ tabname.

${ }^{21}$ Peter Shaw, New Zealand Architecture: From Polynesian Beginnings to 1990 (Auckland: Hodder and Stoughton, 1991), intro 8.

${ }^{22}$ Alexander Trapeznik, Dunedin's Warehouse Precinct (Dunedin: Genre Books, 2014), 8.
} 
prone Buildings) Amendment Bill in 2016. In 2011 the DCC reviewed their earthquake-prone policy-just after the Christchurch earthquake-and this review came into practice in 2012. This review moved the council from taking a passive approach to earthquake-prone buildings, to taking an active approach. This meant that the council contacted owners of potentially earthquake-prone buildings. It undertook an initial evaluation procedure (IEP) to assess the strength of existing buildings and thereby identifying earthquake-prone buildings, letting owners of earthquake-prone buildings know what is required of them and stipulating timeframes for work to be achieved. According to the DCC there are 2800 building on their earthquake-prone list, of which about 340 are heritage buildings; these numbers include buildings waiting for assessment. The numbers of earthquake-prone buildings are gradually declining, as property owners demolish or strengthen their buildings to the target $34 \%$ of New Building Standard or above. The makeup of this list and the timeframes associated with policy may change once the government finalises the Buildings (Earthquake-prone Buildings) Bill 2013. ${ }^{23}$

The DCC has been working through the process of assessing buildings and then moving onto strengthening, with a focus on upgrading public and commercial buildings. Some of their timeframes have changed since 2012 as a result of the area being declared low risk in 2015. The heritage advisor at the DCC believes that there will be changes to the types of buildings that are considered 'earthquake prone', with some that are not being added and some that currently are being dropped. ${ }^{24}$

These changes, plus legal requirements, have led to building owners undertaking the process of retrospective earthquake strengthening. The DCC, like other councils around New Zealand, offers building owners incentives to undertake strengthening work. The incentives are predominantly monetary and are a recognition by the councils that the process of earthquake strengthening can be expensive. These incentives are the Dunedin Heritage Fund Grants, central city re-use grant scheme and rates relief. ${ }^{25}$ None of these funds will cover the full cost of earthquake strengthening work, instead they are designed to help make up the difference between a project being feasible or not. They also act as a 'pat on the back' to

\footnotetext{
${ }^{23}$ DCC Heritage Policy Planner, email message to Imogen Stockwell, October 22, 2015.

${ }^{24}$ DCC Heritage planner, "Research Interview," interview by Imogen Stockwell, October 23, 2015.

${ }^{25}$ DCC Heritage Policy Planner, email message to Imogen Stockwell, October 22, 2015.
} 
building owners for doing the work. ${ }^{26}$ The DCC also provides support for building owners, this can make the process of getting advice and resource consent easier and save applicants time and money. ${ }^{27}$ Heritage building owners receive free advice from the DCC and the Dunedin Heritage Fund is solely for heritage building owners to apply for - the fund is designed to offer "incentives for the owners of heritage and historic buildings to assist with improvements to structural performance, other types of adaptations to code requirements, and a range of work related to the restoration and re-use of heritage buildings." 28

Residential buildings are generally not considered to be earthquake-prone, unless they are two or more stories and contain three or more units. Therefore there are few earthquakeprone houses, the residential buildings on the earthquake-prone buildings' list are predominantly apartments, or in non-residential uses like offices, museums, schools, etc. The DCC heritage planner believes that some multi-unit residential houses may be added in the future when central government releases their new national earthquake prone buildings requirements. ${ }^{29}$ In Dunedin there are 737 heritage items, most of which are buildings, protected under the Dunedin City District Plan. The Council considers new additions to the heritage register every four years, and aim to list a range of heritage places from different periods of the City's history. ${ }^{30}$ There are approximately 411 homes on the DCC heritage list, including houses that are used as offices. Of these, approximately 110 are also on the New Zealand Heritage List, administered by HNZ. Of the 411 homes protected by the DCC District Plan, four have interior elements protected. Two of these houses are Olveston and Larnach Castle, both of which are tourist attractions. ${ }^{31}$

HNZ local offices are working with local councils in the implementation of earthquake strengthening by providing information on retrospective seismic strengthening in heritage building, additional guidance for heritage building owners, assistance with the management of heritage funds. ${ }^{32} \mathrm{HNZ}$ manage their own National Heritage Preservation Incentive Fund which is for private owners of Category One buildings. These grants can be given to owners

\footnotetext{
${ }^{26}$ DCC Heritage planner, "Research Interview," interview by Imogen Stockwell, October 23, 2015.

${ }^{27}$ DCC Heritage planner, "Research Interview," interview by Imogen Stockwell, October 23, 2015.

${ }^{28}$ Dunedin City Council, Earthquake-prone Building Policy, 10.

${ }^{29}$ DCC Heritage Policy Planner, email message to Imogen Stockwell, October 22, 2015.

30 "Vision", January 9, 2016, https://www.dunedin.govt.nz/whats-on/dunedin-heritage/vision.

${ }^{31}$ DCC Heritage Policy Planner, email message to Imogen Stockwell, October 22, 2015.

${ }^{32}$ HNZ Area Manager for Otago and Southland, "Research Interview," interview by Imogen Stockwell, October $22,2015$.
} 
of buildings on the New Zealand Heritage List who are doing work that might be considered earthquake strengthening. ${ }^{33}$ Although earthquake-prone buildings policies only require buildings to be $34 \%$ NBS, HNZ advocates for $67 \%$ NBS for strengthening heritage buildings. When it comes to assisting homeowners with earthquake strengthening, HNZ provide information particularly on seismic strengthening chimneys as this is a main concern for homeowners. A lot of the information they are currently providing came out of the experiences of the Canterbury earthquakes. Although HNZ work with local councils, such as the DCC, they also work independently. Their incentive fund is administered separately and targets a slightly different property owner-private owners. HNZ also get specialist engineers, such as Win Clark, to speak at public forums. They also use these specialists for peer reviews of proposals when appropriate. ${ }^{34}$

Earthquake-strengthening and heritage protection are the two official processes impacting heritage homeowners I examine in this dissertation. As this chapter has outlined there currently is momentum behind earthquake-strengthening in New Zealand, and often this process works alongside heritage protection. Commercial and public building owners are often required by earthquake-prone building policies to undertake earthquake strengthening, a process in which they are eligible to apply for incentives and support from local authorities. DCC is among the councils encouraging building owners to earthquake strengthen their buildings. One group of building owners who are generally exempt from the requirements of these policies are private heritage homeowners, despite this a number are choosing to do this work. The next chapter examines the findings from the interviews conducted as part of this research. They explore what the authorities on official heritage, HNZ and the DCC, are doing to encourage heritage homeowners to earthquake strengthen their buildings. Three heritage homeowners were also interviewed and the findings explore their answers to questions about official heritage, their personal connection to their building and why they chose to earthquake strengthen their homes.

\footnotetext{
${ }^{33}$ HNZ Area Manager for Otago and Southland, "Research Interview," interview by Imogen Stockwell, October 22, 2015.

${ }^{34}$ HNZ Area Manager for Otago and Southland, "Research Interview," interview by Imogen Stockwell, October $22,2015$.
} 


\section{Chapter Two \\ Interviews with heritage professionals and homeowners: Views from top-down and bottom-up}

Within this atmosphere of earthquakes, legislative change and earthquake-strengthening incentives, some homeowners are taking it upon themselves to retrospectively strengthen their homes. These homeowners are generally not the target of the legislation or the associated incentives from local authorities. From my data collection I wanted to find out about more than just earthquake strengthening, I also wanted to find out about homeowners' relationships with the tangible and intangible elements of their homes, and how the councils are providing for this. This chapter reports the findings from the five interviews that were conducted in the data collection phase of this research, and is divided into two sections, Authorities and Homeowners.

\section{Authorities}

The two professionals interviewed were the HNZ Area Manager of Otago and Southland, and the DCC Heritage Policy Planner. The authoritative findings are divided into three sections to reflect the format of the interviews: domestic heritage protection in Dunedin; earthquake strengthening in Dunedin; hypothesizing on why people earthquake strengthen their homes.

\section{Domestic Heritage Protection in Dunedin}

This research explores the ways in which authorities and communities work together to achieve positive heritage outcomes. Therefore, it was necessary to clarify how the heritage authorities in Dunedin incorporate property owners-homeowners-into their process of protection. HNZ and the DCC have a number of ways to register buildings; the homeowner's role in each method differs as follows. Both organisations will consider listing houses that have been nominated by the homeowner, but there are other avenues for protection. Additionally, both organisations have the ability to list houses without the consent of the building's owner. HNZ takes nomination of a home by the owner as approval for protection, if a third party nominates a building the homeowner is consulted after a process of research and internal review where HNZ decides the level of significance of the building. Owners can input at several points, they are contacted and consulted prior to public consultation and can 
submit formally to calls for public consultation. The HNZ board considers proposals and decides whether a building is listed, or not and if so, its level of significance. "We don't require owner agreement to enter something onto the list, so technically a building or a site could be entered onto the list even if someone was opposed to it, if we believed the values were that significant and the points raised in a submission did not affect significance, or unreasonably affect the buildings future." 1

The DCC has three ways that houses are listed on their district plan, and in recent years their process has changed. One method was through HNZ, in the past houses were listed as a result of being registered by the national body. Today the DCC takes a more considered approach to protecting buildings on the New Zealand Heritage List, however, the DCC Heritage Policy Planner "suspect[s] in the case of most houses though that if HNZ lists them and we can get the owner approval, we will then subsequently put them in the plan as well." 2 A second method of registering is through protected precincts, where a specific area will have controls in place to protect against uncharacteristic development. Previous administrations at the DCC would protect every building in a heritage precinct regardless of its heritage value, today they are more cautious with their application of heritage protection in these areas. The third method is when the owner nominates their building. According to the interviewee "it's less common, but it does happen". The homeowner's role in this process is sometimes as an instigator, or "more often they're someone we consult with and we'll present the information that we have and we'll check with them whether they are happy to have their building listed." Like HNZ, the DCC can list a building against the owner's wishes, however, the DCC prefers to list buildings with the consent of the owner: "Over the last few years our focus has always been trying to get owner approval before we list them, so that sometimes means we negotiate quite heavily with the owner around which features are going to be protected." This level of homeowner involvement is consistent with the 'top-down' heritage where the authority has the ultimate power to make the heritage decision, however, the reluctance by the authorities to use this power suggests that the mind-set within these organisations is towards a partnership not a dictatorship.

\footnotetext{
${ }^{1}$ HNZ Area Manager for Otago and Southland, "Research Interview," interview by Imogen Stockwell, October $22,2015$.

${ }^{2}$ DCC Heritage planner, "Research Interview,” interview by Imogen Stockwell, October 23, 2015.
} 
A 'cycle of care' was discussed in relation to heritage objects in the introduction of this thesis, and the literature indicates that the development of a cycle of care within the community is important to ensure lasting positive heritage outcomes. People will care for something because it has value, therefore, I wanted to ascertain how, and to what extent, the authorities assist homeowners in identifying the heritage value of their houses in order to develop an engaging relationship that could result in a cycle of care. The HNZ representative stated that HNZ aims to get homeowners to engage with the heritage of their house. When asked "What does HNZ do to promote the development of a cycle of care for built heritage within the community?", the interviewee spoke about the physical maintenance of the house, in a later question they spoke about less tangible means of engagement. The interviewee stated that HNZ likes speaking with prospective heritage homeowners about ownership and to current homeowners who are planning to undertake alterations about their work. They also provide information on their website for the DCC regarding maintenance. HNZ alerts building owners of funding opportunities to assist with major repairs. The interviewee said that they take a proactive role if they notice buildings with deferred maintenance issues. HNZ hosts public talks on heritage buildings; discussing how to care for them and alter them sympathetically. In 2014 they ran a series of workshops on how to research your home, alongside their Heritage Lost and Found: Our Changing Cityscape exhibition at Otago Museum.

In contrast to $\mathrm{HNZ}$ the $\mathrm{DCC}$ has not been actively encouraging a cycle of care for domestic buildings because the DCC's focus has been on commercial buildings due to the earthquakeprone buildings legislation. However, the work the council has been doing in the commercial sector has provided building owners in general with opportunities like workshops and site visits for people to see what work is being done. The DCC's rationale for not actively promoting residential heritage is because they believe the mind-set is already there. The DCC Heritage Policy Planner claims that "...people tend to maintain things better if they live in them, than if it is just an investment for example." The interviewee believes that over the last five or six years expectations regarding what is acceptable treatment of heritage buildings has changed due to the work the council has been doing in the commercial sector.

I would say that it has done two things, it has changed the perception of what is possible, so buildings that people previously thought could not be restored or were too far gone, they can see that they actually can be, and they can be turned into something 
with a very big use. The other thing it has done is, so that sort of puts a bit of pressure on people to be like "well I was going to just demolish this building, but you know if someone else has done something pretty good with their building that was in worse condition, maybe I won't get away with that through council anymore". The other thing is it raises expectations around what is actually acceptable.

The DCC have seen an increase in concern about the loss of residential heritage in areas close to the University of Otago, "Where property values are changing, houses are being replaced, and they are not always replaced in a way that is sympathetic to the neighbourhood." "...the community expect people to do a better job and they're upping their expectations around building ownership as stewards of these buildings." The interviewee believes community expectation is strengthened by a joint mentality in heritage rich areas, because of a preexisting value of heritage that encouraged them to purchase a heritage house in the first place: "people buy into the area and look after their building in a certain way, because they are with like minded people". This pre-existing appreciation and engagement with the heritage value of a building may pave the way to more open channels of communication between the building owner and the authority, leading to greater understanding of heritage expectations and perhaps allow for greater autonomy over heritage decisions by the building owner due to increased awareness of the heritage value.

Domestic buildings are theatres of the everyday, full of intangible heritage values and stories. These intangibles are often points of personal connection, which contribute to a building owner's relationship with their house. Therefore I wanted to find out how the authorities worked with intangible heritage. HNZ Area Manager sees balancing tangible and intangible heritage as crucial to the conservation process, stating that: “...probably the most important mechanism of that, in terms of ensuring that people understand why their home is significant." ... "But also it's important for the people to understand that the intangibles can be grounded in tangible attributes to the building." The interviewee states "sometimes the intangibles do have grounding in the physical fabric of the building", using the example of a landscape artist's house, where the artist always painted from one room, and as a result the fabric of this room and the view from it was important to conserve. HNZ considers that "...all fabric in some ways should be proven of having heritage value, you have to prove it innocent of having that first, so we should assume that it is guilty of having heritage value and then we try and ascertain what level of value it really does have." This implies that the true heritage 
value of a structure can only be identified through research. HNZ ran their 'How to research your house' workshops to assist people in understanding their house's heritage. These were well attended, with the first sold out, prompting two more to be scheduled. These were "... four hour workshops talking them through how they can find out more information about the building, who lived there, what the history of the building is, what the importance of the aesthetics of the building, maybe as they are now or as they were as built." The interviewee stated that these workshops also emphasised to owners that "the significance is not just held in what's original to the building, it is often about the on-going development of the building and that should be respected as much as the original value, and really making people understand that the house is a backdrop to stories that have been played out through the history of the house."

HNZ sees balancing the intangible and tangible heritage as a process of "...understanding the values of the building...”

So really it's about understanding the significance of the wider building, the wider house, setting, and the exterior and interior spaces of the building, understanding, you know, how they were significant to the original design, and if you like concept, objectives of the architect, of the original owners, the client, what that stands for, what that expresses, and then also how the house was used through its history through to now, understanding how it has changed and whether the fabric that has been added to since it was built, what the significance of that fabric is and what it tells us about the house.

When asked "Does HNZ assist homeowners in recognising that their personal connection to their house is of heritage value?", the HNZ representative answered: "Yes we do, because that is all part of the discussion... someone comes to us and asks us if they can do alterations." HNZ views alteration proposals as a display of current owners "understanding of what they value about the house, what they want to change about the house." When consulting with heritage-listed homeowners about alterations HNZ

...want to understand what the motivations are behind the changes they want to make, and whether in the circumstances, in terms of making the place a comfortable house, 
whether that, in terms of the balance of the possible impacts that we see, whether those are reasonable in the circumstances.

This process of discussion should enable informed decisions where both the authority and the people are able to understand each other's viewpoint and come to an agreement on what has heritage value to both parties.

The DCC representative stated outright that their focus is mainly on tangible heritage, and that the work they have been doing on the histories and stories of buildings has been focused on commercial buildings. The interviewee stated: “... it's not something we tend to do in terms of a lot around the intangible heritage, I think we'll do a little bit more in future..." The DCC perceives the recording of intangible heritage as the realm of others-"it relates to other groups-places like Southern Heritage Trust and others-that do tend to get more involved in recording those stories". The DCC places importance on a building's stories when they are part of the reason a structure is protected. Although the DCC does not actively protect or encourage the protection of intangible heritage, they have been doing miniature histories on many of the commercial buildings in Dunedin as part of reviewing why heritage buildings are listed and protected. Their interviewee hopes that in the long run this practice can be extended to residential buildings, because they have seen positive effects with commercial property owners and greater engagement with the heritage aspect of their buildings as a result of knowing and understanding the histories. This implies that the DCC heritage team do recognise that there is room for improvement, but this is currently beyond their available resources. If the DCC were to conduct short histories on residential buildings it would extend the DCC's actions with regard to domestic heritage to include intangible heritage, and may lead to greater engagement between the homeowners and the heritage of their buildings.

Despite the DCC's interest in tangible fabric over the intangible stories of heritage, they hold the view that: “...for residential buildings, most often they're-unless they're Olveston, or places like that, that has become a museum house-very much their significance is based in the fact they have been lived in and that they are a house, and so you just have to think about that the changes and continuing to have them used as a house is just as important as protecting the fabric.” And their method for achieving this is by: “...establishing what's actually the reason you are protecting something, and making sure that those elements are protected, but also which elements could change to allow people to more comfortably live in 
that building for example." This flexibility is achieved by only protecting elements of the building which are deemed to be significant to the heritage classification of the building. Therefore, only exceptionally important residential buildings are protected in their entirety. Many residential buildings are protected in order to preserve a cohesive streetscape, and in these cases the DCC “...tend to allow people to do what they want internally, or to the exterior of the building at the rear of the building if it's not visible." with the intention of “...still protecting the heritage streetscape and allowing people to make those changes to make places more liveable." The interviewee stipulated that protection "...doesn't mean that you can't make changes, it just means that we want to ensure that we have some control over what those changes are." It appears that the DCC representative viewed that many of the protected residential buildings were special because they are homes.

When asked "Does the DCC assist homeowners in recognising that their personal connection to their house is of heritage value?" the interviewee answered "Probably not, I don't think that is something we do across the board." The miniature histories the DCC have written on commercial buildings have been well received, with owners of buildings saying "oh, I didn't realise that's why it is protected" or "...that these things were significant." Homeowners also consult with the Heritage team when doing alterations, at this point they will often find out why aspects are important and decide to protect that element in their work. The DCC's actions regarding homeowners contrast strongly with HNZ, with the DCC doing little to assist heritage homeowners and HNZ attempting to do much more, especially in regard to education and engagement.

\section{Earthquake strengthening in Dunedin}

This research is investigating how a homeowner's relationship with their home plays a role in their decision to undertake conservation work, in this case earthquake strengthening. Earthquake strengthening is a topical issue for councils and building owners, with authorities using incentives to encourage and aid the process. The DCC has three main mechanisms for assisting property owners with earthquake strengthening. These financial incentives are Dunedin Heritage Fund Grants, the central city re-use grant scheme, and rates relief. The Dunedin Heritage Fund Grants are specifically to assist heritage-building owners with: 
earthquake strengthening, façade improvement and re-use development. ${ }^{3}$ The heritage team has noticed that although the Dunedin Heritage Fund is not able to provide large sums of money, the assistance that they do provide makes a difference-"sometimes the amount of money you're giving is really just a pat on the back, to say we appreciate it, sometimes it will make quite a bit of difference in terms of swaying the profitability or the viability of the project." The assistance the fund provides is not always directly related to the monetary grant, but the support the process provides can save the owner money "...we can save people substantial amounts of money ... through the process itself. So if we take longer to process a consent or if we delay them getting code compliance for example, those can have very big ramifications on projects, you know, if you're not allowing tenants to move in, that could be costing you thousands of dollars per week." This approach is also paired with the council taking a less rigid approach to the consent process: “...if we stick to the absolutely black and white this is what you have to do and don't exercise some discretion, that could make the difference between the project being viable and not being viable, and if we can find ways to work with those owners to stage those works or find alternative solutions for how they might do it, we can end up saving them hundreds of thousands of dollars..." The interviewee believes that financial incentives need to work alongside a supportive environment to achieve positive outcomes for all parties, and ultimately the building.

The DCC does not target homeowners with their funding incentives because few houses are captured by the earthquake-prone buildings policy, as a result the Dunedin Heritage Fund Grants tend to be given to commercial buildings. Residential buildings are not classified as earthquake prone unless they are two or more storeys and three or more units. As a result residential buildings on the list are mostly apartments. The interviewee is aware that there are homeowners who are doing more simple forms of earthquake strengthening, such as stabilisation of chimneys, replication of chimneys, and removal of chimneys. Apparently the DCC has given money to residential buildings-"It's not that we get lots of residential applications and decline them all, it's just that not so many residential people apply to the funding."-and they are in the minority. Recently the Dunedin Heritage Fund has been approached by two landlords who own flats on Dundas Street. These applications were declined, because of concerns over the precedence this move would set. Questions regarding

\footnotetext{
3 "Financial Incentives", accessed December 24, http://www.dunedin.govt.nz/whats-on/dunedin-heritage/howcan-we-help/heritage-fund.
} 
the integrity of their application were also raised, with the feeling that they were just applying for the money.

The other thing was that these weren't owner occupiers of their houses, so these people are already making quite substantial profits off these buildings, and in neither case that we had ... [did] they ever shown any sensitivity to the heritage of the building in the past.

The interviewee's justification for not promoting the fund to residential property owners was due to the need for a public benefit from public funding. They argued that

Commercial buildings are more open to public going in and seeing them, we are always a bit nervous about giving to residential buildings as it is really that no one else except that owner is going to see the benefits of that work, and because it is ratepayer money, in effect we need to make sure that there is a public benefit.

$\mathrm{HNZ}$ and the DCC are working together and independently on seismic strengthening in Dunedin. HNZ has their own initiatives that they implement while also playing a support role to the DCC, assisting them implement the Dunedin Heritage Fund and providing information and advice for property owners. HNZ provides advice and expertise on methods of seismic strengthening, and by working with council they are able to increase owners' understanding of the process. They aim to get information to people as early in the process as possible to avoid unnecessary work, or promoting the idea that the project is too large and expensive, and thus unfeasible. HNZ believes many owners perceive earthquake strengthening as a huge job, therefore the organization aim to get building owners to see the project in broken down stages, focusing on certain elements, rather than the building as a whole. If building owners approach HNZ prior to submitting their application for the Dunedin Heritage Fund, in some cases they will seek engineering advice and have the application and proposal peer reviewed by their advisor. Additionally, they bring consultants to Dunedin to talk to building owners about the process, the options and to give advice where possible.

HNZ caters for private owners through their National Heritage Preservation Incentive Fund (NHPIF), this fund is often used to jointly fund projects alongside the Dunedin Heritage Fund. The NHIPF is focused on Category One dwellings, which a number of residential buildings 
are. The interviewee believes that houses "They're sort of a very important part of the heritage list quite frankly, hence the fact that we have a fund for private owners, specifically." This attitude contrasts strongly to the DCC's perception of greater public benefit from commercial buildings. Between the NHPIF, the support of the DCC and hosting information workshops-such as 'How to research your home'-HNZ are trying to raise expectations surrounding property ownership and strengthening, showing homeowners that seismic strengthening can be reasonably achieved.

\section{Hypothesizing on why people earthquake strengthen their homes}

Central to this research is the consideration of the motivating factors for homeowners to undertake research. During their interviews each professional was asked "Have you noticed any of the motivating factors behind conservation work such as earthquake strengthening?" This question was asked to find out what the authorities thought was motivating building owners to earthquake strengthen when it was not a legal requirement. Both representatives said that the primary reason was safety. The HNZ representative said that the weight of motivations would differ case-by-case but hypothesised other factors, such as protecting an owner's investment and a sense of guardianship of the property. The DCC representative considered a few options, including that people might be "motivated by the fact that insurers or banks are putting more pressure on people... to prove that the building is safe before the bank will loan on it." Both interviewees went on to say that if people are thinking about heritage values, this becomes a motivation when they are considering the best way to undertake the work. However, the largest influence on how something is achieved comes down to cost.

\section{Homeowners}

Three heritage homeowners were interviewed, they are referred to as "Homeowner one", "Homeowner two", and "Homeowner three". The following section follows the same order that the interviews followed: homeowners' understanding and attitude toward official heritage and heritage protection, their personal connection to their house and what earthquake strengthening they have done and why. 


\section{Homeowners' understanding and attitude toward official heritage and heritage protection}

In order to ascertain how top down and bottom up heritage work together, I wanted to find out the interviewee's perceptions of official heritage protection. Only one of the homeowners interviewed had officially protected heritage buildings, but despite this all of the homeowners had a general negative opinion of heritage protection. Homeowner one was the only participant with a heritage-protected home and their view of protection was largely based on other people's experiences. They are aware that there are restrictions on what they can do to their house, as they explained: "So there were regulations on what you could do without permission. And in actual fact we have never struck that, but some of our neighbours have. So for instance, even things like painting the house, you are supposed to have heritage colours. So anything that changes the appearance of the house." ${ }^{\prime 4}$ A lot of their understanding of what they can and cannot do to their home is based on neighbours' experiences and hearsay. They commented that: “... apparently we aren't allowed to change the windows either." This is because they have never been contacted by the DCC in the 16 years they have owned the property. Homeowner one stated that: "We've never been approached directly to say 'you have a heritage house, and this is why we classified it as a heritage house'... So, it would be quite nice to make us aware of what values they have on the property and what is available."

Homeowners two and three both own houses that are 80 years old or older. Both recognise that their homes have heritage value, although neither would seek classification for their homes. Homeowner two would not seek protection because of their negative perception of protection. This perception is based on family experience with HNZ in Christchurch prior to the 2011 earthquake.

They were going to make some changes and modernise their house, appropriately in my mind, there was nothing dramatic. They were going to take it out of the dark-ages and just make it light and good, but they were stymied at every stage, and we never wanted that for this house. Because this house, because I love it, and I think has to keep up to date, and the only way you can do that is without people telling you how to

\footnotetext{
${ }^{4}$ Homeowner one, "Research Interview", interview by Imogen Stockwell, November 10, 2015.
} 
do that. I mean, I don't think you should be constrained by an organisation who, in my view, tried to keep my sister-in-law's house as it was when it was first built. ${ }^{5}$

This attitude is largely based in the homeowner's view of how domestic life has changed since these heritage homes were built, with Homeowner two asserting: "It just isn't the way we live our lives anymore." This perception of heritage protection is reflected in Homeowner two's perception that they have been able to make more changes to their house as a result of their home not being officially recognized heritage: "We made quite a few changes in the kitchen ... I don't know if we would have been allowed to have done that if we had been part of the heritage house programme." Homeowner three holds a negative view of protection, due to perceived limitations on what heritage protected homeowners are able to do to their homes. Although, they admitted that they did not know a huge amount about how heritage protection and how protection orders worked.

To continue the investigation of official heritage, I was curious to know what aspects of their homes they considered to be worthy of official heritage. I wanted to explore their relationship with their house through their understanding of official heritage to gauge their understanding of what official heritage is, as well as their perception of what about their houses they thought others would consider important. To find this out I asked the homeowners what aspects of their houses they thought should be protected if their houses were to come up for heritage listing. Homeowners one's perception aligned with the current official protection of their house; that the front elevation is what should be protected. Homeowners two and three both stated the front elevation as the aspect of the house they would protect of their houses. Homeowner two elaborated more on this point, stating that there were aspects of the interior that they considered to be worthy of protection-"some of the fireplaces ... some of the doorway arches, some of those decorative features..."-as well as the grounds of the property-"If I could put something in place to protect the house it probably would be to protect the grounds around the house so that the house isn't built up." All of the elements the homeowners identify as worthy of protection were tangible heritage.

\footnotetext{
${ }^{5}$ Homeowner two, "Research Interview", interview by Imogen Stockwell, November 20, 2015.
} 


\section{Personal connection to house}

In this section I am interested in the personal connection the owner has with their home, therefore I asked them what they valued about their homes, to which all interviewees answered with physical and non-physical aspects of their home. Homeowner one valued their family, the library and personal objects they have collected. They like the feel of the house: "More than anything else it is the feel of the house, as soon as we walked in we both liked the way it felt... it felt like a home, and we had looked at hundreds of houses, before we chose this one." They consider themselves lucky to have the property, and that their house is now special because it is a family home and has not been converted into flats, like many other houses in their area. Homeowner two values a whole combination of things about the house, inclusive of the memories of bringing up their family in it and how the house has allowed them to live a life of people coming and going. They also value physical features: "I love the way it looks, I love the arches, I love the curved walls, I like the window surrounds, there's features that I actually take pleasure in on a daily basis..." Homeowner three's values were focused on physical aspects, but acknowledged how the physical aspects create an atmosphere that they value: "by accident or otherwise, it's got large windows that face the sunny side, face the north. So it's very sunny and light."

This line of enquiry lead to asking the interviewees what made their house a home rather than a place they reside in. All three summed their answers up in one or two short sentences. Homeowner one's response to this was integrated into a sense of what they value about their home - their wife, the spaces and their personal things. Homeowners two and three were quite explicit, and detached the sense of home from the physical house. Homeowner two explained that: "the home aspect is really the life that goes on inside the house. I mean to be honest, we would have had the same life in another home, the same sense of home would have been wherever we were." Likewise Homeowner three commented: "Well it's the people who live in it."

\section{How and why they earthquake strengthened}

One prerequisite for inclusion in this research was that the interviewees had undertaken earthquake-strengthening work on their homes. The nature of the work each homeowner has completed differed depending on a number of factors, including the type of house, budget,

\footnotetext{
${ }^{6}$ Homeowner three, "Research Interview”, interview by Imogen Stockwell, December 11, 2015.
} 
and timeframe. The following breaks down the work house by house. Homeowner one has removed a chimney and replaced a large number of the joists underneath the house, which were rotten, decayed and infested with borer beetle. Homeowner two has reinforced their masonry chimney with steelwork. Homeowner three has undertaken the largest amount of earthquake strengthening, they have replaced the concrete tile roof with long run steel, bolted the frame of the house to the concrete foundations, removed two chimneys, and restrained their water cylinders with steel straps. The common action by all three homeowners has been to address their chimneys. The associated cost of their earthquake strengthening work differs greatly between homeowners, reflecting how much work they have done. Homeowner one spent $\$ 5,000$; this amount does not include the man-hours that the homeowner spent assisting the work. Homeowner two spent near to $\$ 15,000$. Homeowner three has spent around $\$ 350,000$ undertaking earthquake-strengthening work on their house since they purchased it in 1981. None of these homeowners had received financial assistance to undertake their work.

Earthquake strengthening was not a legal requirement for any of these homeowners, so I was curious about what motivated the work. The main motivating factor for the respondents was safety. All three homeowners expressed concern for the safety of themselves and their families as their main concern. Other factors included an awareness of New Zealand's status as an earthquake-prone country and the experiences of family and friends in Christchurch. Homeowner one started their work as part of renovations to increase useable space: "it wasn't until after we removed one of the chimneys, which is a huge stack, that you realise just how vulnerable the house could be in an earthquake, because there are tonnes and tonnes of bricks that are just balanced... the mortar is not very good, all the bricks needed is just a little tap and they will fall out." Homeowner two's work was motivated by fear of their chimney coming down after experiencing an earthquake: "With one of the [Christchurch] earthquakes I was lying in bed ... I heard what sounded like the chimneys going *kachink**kachink* *kachink* ..." Homeowner three has been conscious of the need for earthquake strengthening in New Zealand since they brought the house in 1981, as they explained "From the first time when we moved into the house I was aware that New Zealand is an earthquake prone country. And I guess from the very beginning in $1981 \mathrm{I}$ was looking to take reasonable precautions against earthquakes. General planning from the outset, no specific event.”

The Canterbury earthquakes were a factor for homeowner's one and two when making decisions about their earthquake strengthening. Homeowner one took down their chimney 
"because the lesson that everybody learned from Christchurch was that the chimneys, when they came down, did a hell of a lot of damage." While Homeowner two learnt from their family's experiences in Christchurch: “...in that family home in Christchurch the chimney fell down away from the house rather than into the house, so it fell on a car and absolutely demolished the car. But if it had gone the other way, my niece was in the room beside it, and I think that was what really motivated me, was the fact that human life could be lost, and it did cost quite a lot of money, but I thought it was money well spent.”

These findings have reported some of what is happening on the ground-be it what the authorities are doing and why, or what the homeowners are doing and their thoughts on their homes. The biggest difference between HNZ and the DCC is in the way they work intangible heritage into their practices, with the former recognising its importance and taking some measures to encourage engagement and the latter focusing on tangible heritage. Both the DCC and HNZ are working with property owners to encourage and assist with earthquake strengthening, however, due to legislative focus, domestic homeowners are not the target. One point that has arisen is the apparent lack of communication between the authorities and homeowners, which has lead to negative perceptions by the homeowners of official heritage management. The following chapter will analyse and discuss the findings reported here, placing it in the context of critical heritage studies. 


\section{Chapter Three \\ Analysis and discussion: \\ It's all about the people}

The previous chapter reported on the findings of the five interviews undertaken for data collection for this research. These qualitative one-on-one interviews were with two different groups-official heritage practitioners representing the DCC and HNZ and three heritage homeowners. This chapter places these findings in the context of the research and analyses them in relation to the research questions: is there a heritage relationship between a homeowner and their house? does this heritage relationship contribute to how they care for and regard their home? and is this relationship a motivating factor for a homeowner to undertake earthquake strengthening? These questions are addressed below by analysing what is happening in official and then homeowner heritage spheres, and next looking at the interactions between these two spheres. Finally, consider these in relation to the motivations for earthquakes strengthening. Throughout this chapter I refer back to the literature discussed in the introduction of this dissertation, particularly the ideas of 'top-down' and 'bottom-up' heritage, Authoritative Heritage Discourse (AHD), developing a cycle of care and the link between home and safety.

The findings from this research show that the heritage authorities in Dunedin work according to a 'top-down' approach to heritage. This statement is based on the legislative powers of the two organisations interviewed-HNZ and the DCC-and the authoritative rather than peoplesbased heritage practice of these organisations. Both authorities have the ability to protect buildings against owners' wishes, they endeavour to get owner consent, but it is not necessary. In regards to heritage management, the DCC appears to be relying on the trickle down effect: supporting commercial buildings-as reflected in the respondents' interview statements about seeing flow on effects-and relying on the work that is being done in that area of heritage conservation, and the ideas it promotes, flows into the domestic sector. This is emphasised by the incentives promoted by the council, which all target commercial heritage which have a perceived public benefit and a legal requirement for the work to be completed.

Because HNZ's focus is on the official built heritage, their work is aimed at their protected buildings; their processes focus on the protected aspects of these buildings and their overall 
aesthetics, and when dealing with the intangible stories or history of the structures they focus on the official history. The public programmes that HNZ have run, such as 'How to research your house' workshops, focused on the history of the house prior to the current owners. Amateur researchers learned about their home's architect, the aesthetics and style of the building, the original owners, and what changes have been made to the house since it was first built. It appears that no emphasis was put on modern history with little encouragement for the researcher and current owners to record their lives in the place. The lack of emphasis on current owners means that HNZ are overlooking a strong point of engagement and a major pull point for the owners. This is an area with room for improvement, and the solution may lie in current museum practices which have moved to emphasise community engagement.

The findings highlighted that at an official level little is being done for domestic property owners, less is being done for domestic intangible heritage, and it appears that nothing is being done to recognise and assist owners with recognising a personal heritage relationship with their home. This is concerning because it seriously undermines the formation of a system of care. Dean Sully's discussion of a system of care has strong ties to community-led heritage: finding out why a community places importance on their heritage is crucial to establishing processes that aid the retention of heritage, this principle translates to personal heritage as well. ${ }^{1}$ If authorities want homeowners to look after their properties according to official methods, they need to encourage homeowners to engage with their properties on a personal level and acknowledge why their home is important to them, not just on an official heritage level.

It is evident from this research that homeowners do develop a relationship with their house in the sense that it is the backdrop for their daily lives, the setting for life events and a source of endless stories of children growing up, climbing trees, and sliding down staircases in sleeping bags. This relationship contributes to the owners' wish to make their home comfortable and to change it to fit their lifestyles as a functional family home. The development of a relationship for heritage homeowners is no different, this relationship is, in its own right, a heritage relationship-part of domestic heritage-and contributes to the decision to care for, maintain and alter their homes to make them comfortable places to live. Their relationship to the non-personal heritage of their homes comes into play when they are doing alterations and

\footnotetext{
${ }^{1}$ Sully, 2015, 296.
} 
maintenance-regarding how they go about doing work as sympathetically as possible. However, the way that heritage homeowners identify with the heritage of their homes is grounded in ideas of official heritage and ideas criticised by Laurajane Smith's analysis of Authoritative Heritage Discourse (AHD).

The homeowners interviewed have developed a relationship with their house's heritage, this is evidenced by a number of points they made and appears to be due to multiple reasons. They all believe the maintenance and alterations they do are sympathetic to the style of their house. Although, they do not try and recreate a home from the era the house was built. Homeowner two realised very quickly that they didn't want to fill their house with furniture from the era it was built, because it would have become a museum-stale and lifeless-and not the comfortable family home that they desired. The homeowners recognise the character of their houses is part of the buildings' heritage. The homeowners have engaged with the history of their buildings, they all know the history of their homes and can recount previous owners, when the house was built, and who designed it, among other things. Despite homeowners' focus on the tangible heritage of their houses, they do develop a connection with the intangible heritage of their homes, for example, by considering what the original purpose of rooms was. Homeowner one's house has a library, this room has been either a library or an office to previous owners, and was a place where a previous owner performed marriage ceremonies. As a result when the current owners got married they decided to have the ceremony in the library. The interviewed homeowners have countless tales about their lives in their houses and each acknowledged that they would be interested in leaving a record of their lives in the house with the file upon selling the house.

Despite this personal level of engagement, homeowners' view of the heritage of their house is based in the authoritative discourse of heritage. They only thought to identify elements of their buildings which would fall under AHD as having heritage value: the age of their building, tangible aspects such as the street aesthetic, facades, front elevations, and the place their house has in a heritage or character area. This was particularly notable when you consider that only one of the homes is officially-protected heritage. It implies that the homeowners' understanding of heritage is greatly influenced by official channels and the language they use, it also suggests that there is a lack of awareness about intangible heritage and that there $i s$ heritage value in the history of the buildings. Homeowner three owns a house that was built for and owned by a prominent Dunedinite who has strong ties to the 
University of Otago and who has been identified as significant by the DCC in other areas of the city. However, this tie to an important figure was not what the homeowner considered to be of heritage value, instead they noted the physical appearance and features of the building. Intangible heritage of the domestic setting is not a current focus of local authority activity, but this is an area that they could look at improving, although the biggest issue may be working out how to do this on a practical operational level.

The lack of recognition of intangible values by the homeowners, and the local authority, in domestic dwellings is particularly problematic when we consider the primary use of these buildings-to be homes. Central to this is articulating what makes a house a home, a key focus of this research. Based on the findings of this dissertation the answer is relatively straight forward: the people. All three homeowners said that it was their families that made their heritage houses into homes; one homeowner even claimed that they could have lived their lives in any house. However, when the interviewees talked about their favourite memory or a stand out moment from their lives in their house, they chose events which their home provided for, such as big birthday celebrations and weddings. It is evident that these large old houses provide spaces that allow for special life events and the homeowners were happy to have celebrated them in their own space. In regarding the heritage of their houses and whether this contributed to the sense of home, each homeowner acknowledged how the character of their house helped to create an atmosphere that they enjoy living in. Each homeowner had lived in their home for at least 16 years, and this length of time seemed to be of importance to the homeowners. As the interviewer you got a sense that the respondents considered that the longer they were in the house the more they became a part of the history of the house.

When asked about their lives in their home the homeowners did not talk about the changes they have made or the physical house, rather they talked about their lives in the building. They are proud about the alterations and additions they have made, but that is a part of homeownership and not crucial to their lives. Although, each homeowner made the statement that the changes they have made have been to improve comfort levels and to make it suitable to their way of life-with statements such as "We just don't live like that anymore" in relation to having servants quarters and a separate scullery and kitchen. The changes were not to dramatically change the appearance or the atmosphere of the house, but to make it comfortable to live in and to feel more like their home. This highlights an important point, 
that any form of heritage protection surrounding domestic dwellings needs to take into consideration two key points. Firstly, that the intangible heritage of these places is protected, because it is this heritage that is central to relationship forming and reflects the way homes act as backdrops to daily life. Secondly, that any protection of the physical building is done in a way that does not limit its function as a home. This is where officials can step in and use open channels of communication with the homeowner to allow for the needs of the property owner, the use of the home and the right level of heritage protection.

Key to working within the field of Critical Heritage Studies is considering how 'top-down' and 'bottom-up' heritage work together. This point was one of the main motivations for interviewing official heritage professionals and heritage homeowners, since it would enable this research to investigate the two viewpoints and see how they interact to achieve positive heritage outcomes in the form of retrospective earthquake strengthening in domestic heritage dwellings.

Both the officials and the homeowners see homeownership as a form of guardianship of the structure, one that will pass onto future generations upon the sale of the property. This draws parallels to Māori ideas of kaitiakitanga; an intangible relationship that passes from generation to generation. ${ }^{2}$ Although it is not within the scope of this research to explore the ideas of kaitiakitanga, it is worth mentioning because this could be a place to approach the issue that Alison Wain highlights of dealing with intangible heritage in Western populations. ${ }^{3}$ There are parallels between Western and non-Western ideas that are pertinent to heritage. The heritage professionals were quite eloquent in their articulation of building ownership as a form of guardianship, where we temporarily care for a place and over time it will pass to future generations. The homeowners were a bit more pragmatic in their response; all homeowners accepted that upon selling they give up their rights to the house. Although all three homeowners stated that future owners would and should be able to do what they like with the house since they would have given up their rights upon sale. However, in some cases there appears to be a form of vetting that happens during the selling process. Homeowner one said that they were surprised to get their home because they thought it was outside their price range. The previous owners received higher offers, but accepted less money because the

\footnotetext{
2 "Kaitiakitanga: guardianship, stewardship of Māori taonga in museum collections." Conal McCarthy, Museums and Māori: heritage professionals, indigenous collections, current practice (Walnut Creek: Left Coast Press, Inc., 2011), 264.

${ }^{3}$ Wain, 2014, 53.
} 
current homeowners wanted to keep the house as a family home and not develop it into flats or studio apartments. The idea of guardianship and passing on the home to the right people to look after it are relatable to the concept of kaitiakitanga, and is perhaps a place for further study. In the domestic setting, it could be as simple as homeowners ensuring that their house is purchased by the right kind of people, ie. that it passes onto another family so as to continue its use as a home. In relation to this research though, it further enforces the notion that there is an intangible heritage relationship between a homeowner and their home.

As I have established in this research, there does indeed appear to be a heritage relationship between the homeowner and their house. This relationship requires nurturing to develop and ensure that maintenance and alteration undertaken by the property owners have a positive heritage conservation outcome. If authorities encourage homeowners to engage with the heritage of their buildings and to recognise that they are contributing to the building's heritage, they may be more receptive to acknowledging previous owners' heritage within the structure when maintaining their homes. However, this does not appear to be a priority for either authority. The DCC claims that they aren't doing much for homeowners and although HNZ claim to, their language and methods appear to be embedded in authoritative not peoples-based heritage practices. To emphasise this disconnect between the authorities and the homeowner, Homeowner one claims they have never been contacted by the DCC regarding the heritage protection on their house in the 18 years they have owned the property. Both the DCC and HNZ representatives stated that they have found that if people know why their buildings are protected-exactly what aspects and the history that forms the basis for this protection-the owners are more willing to work within the protection regulations. This mindset has not yet become part of the process surrounding private domestic protection.

Homeowner one stated that they would like to know more about why their house is protected, but finding this out required them to initiate the process and they believed that this would cost them money. The lack of interaction between the authorities and homeowners leads me to consider how the interviewed homeowners view protection, and based on the above, it is not surprising that this perception is negative. Although HNZ have hosted workshops as part of a collaborative exhibition, there is room for greater engagement with homeowners by both authorities.

All three homeowners have a negative perception of protection in regard to how the authorities enforce the associated legislation/restrictions, and how they communicate with the 
owners of protected buildings. All three homeowners based their perception of protection and the authorities via second hand accounts and hearsay from other heritage homeowners. Homeowner one, the only one whose house is protected, has never been contacted by the district council, and their perception that the council will either limit what they can do or that initiating a process will cost money discourages them from initiating contact. They base their knowledge of what they can and cannot do to their home on neighbours' accounts, architect consultants and the limited information they learned when they first brought the house. There also appears to be a conflict between the concept of protection and the mentality around property rights in New Zealand. Homeowner one felt that because they own the building they should be able to do what they want, and be trusted to preserve its heritage.

The previous chapter outlined what the authorities are doing to assist homeowners with the process of earthquake strengthening and how homeowners undertook their work. The pertinent question here is how are these two sectors working together. DCC has stated that they are not doing much to assist homeowners with earthquake strengthening, although in the long run would like to extend the benefits offered to commercial property owners to include domestic. It would be especially helpful if they were to extend it beyond the financial incentive and extend their relaxed, less black and white, approach to consulting with property owners to the domestic sector. However, the DCC representative did state that it is hard to justify allocating grant money-which is public money-to private dwellings because there is less public enjoyment/interaction with homes than with commercial buildings. This attitude seems to overlook the fact that this money is ratepayer money, that homeowners are ratepayers and that commercial buildings are not necessarily open to the public on a regular basis. There are instances around New Zealand of these heritage funds being available to homeowners. The Wellington City Council has a Built Heritage Incentive Fund, which private owners of heritage registered buildings are able to apply for. Money from this fund has been distributed to homeowners. Also, if a building has been registered as having official heritage value to the wider community then there is an inherent public benefit. HNZ's own fund is available to private property owners, including homeowners. However, this is only available for properties on the New Zealand Heritage List. This means that none of the homeowners interviewed for this research would have been eligible for financial assistance for earthquake strengthening. 
It appears that homeowners are unaware of financial assistance, as homeowner one did not know about any financial incentives for earthquake strengthening work until the interview for this research. They said that if they were able to access financial aid in the future they would consider removing the second chimney. They also see the protection as so restrictive that they have done their work without consulting the council for fears of cost and prohibition of work. All three homeowners undertook their work without financial assistance from the authorities. When it came to advice for work, whether it was earthquake strengthening or not, homeowners sought it from professionals outside of the heritage authorities, such as architects and stonemasons. Homeowner two sought assistance in the form of advice from non-official channels such as experienced craftsmen and overseas expertise to strengthen their chimney. It is evident from this research that there is a lack of interaction between the authorities and homeowners, this leads us to question what role the each party should be playing in the heritage conservation of domestic homes.

Who is the expert? This question is a valid one when we are discussing the interaction between 'top-down' and 'bottom-up' heritage. It is particularly pertinent when the heritage object in question is a domestic dwelling where the main role is to serve as a home. In this setting the homeowner is the expert about the home aspect. They are the ones who can: articulate what they like or love about their house, why they chose to do specific work, tell the stories about their lives in the building, and how the house played a role in these stories. Official heritage practitioners are not in a position to be the expert about these values, especially not the intangible heritage that transforms a house into a home. They are an outsider to the process of living within the space and the daily interaction with the heritage fabric of the building. Heritage professionals can provide advice about care and maintenance of heritage properties, but they cannot be seen as the expert in the case of domestic heritage.

Central to this research is what motivates homeowners to undertake retrospective earthquake strengthening on their heritage homes, when these buildings are outside the scope of earthquake-prone building policies. The previous chapter reported the findings which reported the hypothesising and discussion with official heritage representatives as to what they thought motivating factors for homeowners were, as well as the three homeowners' individual motivations for performing their work on their houses. The following analysis is based on these findings. The one motivation that was regarded as key by both official representatives and the homeowners was safety. The following discusses how a heritage 
relationship plays a role in retrospective earthquake strengthening, as well as a discussion about the difference between the hypothesis of the official interviewees and the real motivations behind the homeowners' work.

All homeowners stated that they have never considered demolishing their homes. Homeowner one stated that if they were to rebuild their home they could never rebuild the character, and the character was one of the aspects they like. Homeowner three stated that they thought the character of their building was part of the heritage of their home. The age of their homes makes them more aware of the risk the building is to earthquake damage, for example: mortar holding bricks in place has aged and makes a chimney stack less stable motivating them to do the work before it is too late. The heritage of their building plays a role in determining how the work is done. All homeowners acknowledged that their work complemented/was sympathetic to the style and age of their homes. This was true of their interior and exterior work. Homeowner one took down a chimneystack that was not visible to the street. Homeowner two strengthened their chimney in a way that is not easily evident, also when doing renovations they intentionally decided not to put doors from the lounge to the exterior living area because they did not want to compromise the original masonry of the building for the modern notion of indoor outdoor flow.

Both authorities mentioned that social pressure and expectations around what can be done to heritage buildings would be a contributing motivation for homeowners to do work. Both representatives claimed that the work their respective organisations are doing is raising expectations associated with heritage building ownership. The DCC's method is by motivating commercial building owners through incentives and hoping that the work being done in the commercial sector is creating an atmosphere for strengthening. HNZ use their channels through the DCC and their private owner heritage grants to assist official heritage homeowners to complete work for the purposes of conserving official heritage elements. These methods are continuations of the notion of the trickle down effect. However, based on the interviews conducted for this research homeowners are motivated first and foremost by safety for their families, they are also influenced by the tales and experiences of othersespecially family and friends in Christchurch-and another major motivation is the opportunity to undertake the work due to other planned work. The earthquake strengthening is a by-product of other alterations; homeowners do other work to make their homes more comfortable and do some strengthening work at the same time. 
This research has highlighted some issues with the process of heritage management in Dunedin. There are two primary problems this dissertation has addressed: firstly, a breakdown in communication between the authority and the homeowner, and secondly, managing and identifying intangible heritage while also balancing it with tangible heritage. In order to deal with these questions, I would argue that there is an urgent need for the development of a concept of "Domestic Heritage" that caters for the needs of a sphere based in personal experience, life stories and changing needs. This concept developed through this dissertation requires further research in order to create the appropriate framework for it to be applied to the heritage sector. The refinement and application of a theory of Domestic Heritage would equip heritage officials to better deal with the issues of communication and intangible heritage highlighted above, as well as providing a framework for dealing with personal heritage values associated with physical heritage. This in turn, I believe, could be used in heritage conservation assessments and plans. Domestic Heritage should incorporate a number of the ideas discussed here, such as homeownership as a form of guardianship, the development of sustainable communication channels between heritage authorities and homeowners, and the encouragement of continued research into how authorities and communities can work together to achieve positive heritage conservation. The following conclusion contains recommendations for professional practice along these lines. 


\section{Conclusion:}

\section{Towards a Domestic Heritage}

This dissertation has examined the relationship that homeowners have with their houses, how this relationship impacts their decisions to undertake earthquake strengthening, and how heritage authorities allow for homeowner relationships in their heritage-protection process. The research was placed within the theoretical framework of Critical Heritage Studies, which allowed for the investigation of how 'top-down' and 'bottom-up' heritage practices work together to achieve heritage conservation outcomes. In finding out what makes a house a home, and what motivates homeowners to earthquake strengthen their homes, various concepts have been explored. Ideas that have been examined include intangible heritage and its application to Western heritage practices, the strength of peoples-based heritage practices, and the development of a cycle of care when working with the community. These theories guided the development of this research, and the questions asked of the officials and heritage homeowners, who were interviewed. The findings have highlighted the main motivation for respondents undertaking earthquake strengthening, as well as their attitudes toward heritage protection, local council heritage-provisions practices, and their relationship with their homes.

Earthquake strengthening in domestic dwellings was the focus of this research due to its topical nature and its current influence on built heritage conservation in New Zealand. Heritage buildings and the retrospective earthquake strengthening of these buildings has become a hot topic since the Canterbury earthquakes of 2010 and 2011. In general earthquake strengthening and associated policy has been focused on commercial buildings, meaning that residential heritage buildings have largely been unaffected by policy changes. However, some homeowners have been undertaking what is often perceived as an expensive and timeconsuming process themselves, and are choosing to earthquake strengthen their homes. This research aimed to investigate the motivations behind heritage homeowners choosing to do this work, and whether the home's 'heritage' is a motivating factor.

The conclusions of this dissertation are based on the analysis of qualitative data collected from the case study of Dunedin, which included five interviews plus secondary sources and policy documents, which allowed me to explore motivations for earthquake strengthening of built domestic heritage in a seismically "low risk" city in New Zealand. Due to limitations in 
time, and resources, and due to the exploratory nature of the research, it was decided that a small sample of in-depth qualitative interviews would suit the nature of this topic better than a larger sample size consisting of quantitative surveys or more structured interview questions. Given these potential limitations the application of these results to a wider population, or one outside of Dunedin New Zealand, should be done cautiously.

Central to this research has been the question of "What makes a house a home?". The answer from the findings of this research was straightforward; according to the three homeowners interviewed it is the people who live in the house who make it a home. The property owners had developed a relationship with their homes as a result of living life with their families: wives, husbands, partners, children and other loved ones. What people appear to like about their home is an ability to live the life they wish to in it, for example, having celebrations such as weddings or major birthdays, and generally having quality family time in a comfortable environment. They do not seem to favour specific physical elements, or heritage fabric, but instead value the way the physical house provides an atmosphere or a stage to live their life. The homeowners interviewed liked to have autonomy over the decisions they make about changes to their houses. There appears to be a relationship to the physical building in the sense that all three homeowners saw themselves as guardians of their homes. However, when they sell the house they pass this guardianship on and forfeit any right to have a say in the building's future.

I wanted to find out whether this relationship with their home was a motivation for earthquake strengthening. The questions of why homeowner's earthquake-strengthened their homes were not only put to the homeowners interviewed, but also to the two heritage professionals interviewed. All five interviewees answered with concerns for the safety of those living in the house as the main motivation. The homeowners also expressed an awareness of the vulnerability of New Zealand buildings to the ravages of earthquakes either as a result of previous consideration or lessons reinforced from the Canterbury earthquakes. A relationship to the heritage of a home does influence the decision making process. While it appears not to be a central motivating factor, it plays a role in how the homeowner undertakes the work.

A significant issue that has emerged from this research in relation to the interaction between 'top-down' and 'bottom-up' heritage is the apparent lack of communication between the local 
authority and homeowners, and the adverse flow-on effects of this lack of communication, namely a negative opinion of the authorities by the homeowners interviewed. This has resulted in homeowners basing their opinions of heritage protection and council involvement in earthquake-strengthening on second hand information and often negative accounts of interaction with the heritage authorities. This perception needs to be addressed by the authorities if they wish to develop a more positive relationship with homeowners. If authorities want homeowners to look after their properties according to official methods, they need to encourage homeowners to engage with their properties on a personal level and acknowledge why their home is important to them, not just on an official heritage level. This engagement will need authoritative backing in order to get the ball rolling. HNZ found that their 'How to research your house' workshops were well received, therefore I would argue that public programmes such as workshops, public talks, forums for shared experiences, and a platform for people to communicate their experiences, would help develop engagement and open up communication channels.

Prior to this dissertation there had been only moderate research conducted into the relationship between a homeowner and the heritage of their home and how this relationship impacts their decision to make conservation decisions about their homes. Hence this is exploratory research, and will hopefully lead onto more research in the area. Although this research has been framed by Critical Heritage Studies I have taken theories from museum studies and applied them to heritage management practices. There are methods of public engagement in museums that have greatly advanced the relationship between the museum and the community they serve: if these methods could be applied to the relationship between heritage authorities and the communities it is likely that there would be more open channels of communication, leading to a more positive relationship. ${ }^{107}$

This research has laid the first section of groundwork into the formation of what I have called 'Domestic Heritage', providing a framework through which to approach heritage within the domestic sphere, and provide an approach to balancing the intangible and tangible heritage that is interlinked in this sphere. The research has highlighted that it is the people who make a house a home. The concept of home is tied to the lives lived in it and the stories that are remembered, and this intangible concept is closely tied to the physical house which has

${ }^{107}$ Sheila Watson, Museums and their Communities, ed Sheila Watson (London: Routledge, 2007). 
provided the stage for the production of these lives. Furthermore, I would propose that such a Domestic Heritage be firmly grounded in Sully's ideas of 'peoples-based' heritage. A form of Domestic Heritage would provide an approach to implementing the recommendations that have come out of this dissertation. In line with the limitations of the research, however, these recommendations are based on only five interviews, and further investigation may be required if these recommendations are to be put into practice. The first set of recommendations regard the relationship between the authority, the homeowner and the homeowner's house, the second set refer to earthquake-strengthening.

First, I would recommend that heritage authorities increase their efforts to get current homeowners to engage with the heritage of their buildings. Heritage authorities should also focus on the heritage relationship the current homeowners have with their home, inclusive of their lives in the building, this may provide an 'in' for homeowners to identify with the various levels of heritage that their homes have. Second, I would recommend that the DCC develops more open channels of communication with heritage homeowners-they should be endeavouring to let listed property owners know what they can and cannot do to their homes, showing them that they support their work and they will assist them in achieving positive heritage outcomes. In addition to this open channel, it is recommended that this information is kept current; heritage legislation is continually changing and councils need to be advising homeowners about these changes and how they will affect them. Third, officials could consider providing a platform for current owners to record their histories and lives at the house. This would serve multiple functions including: encouraging the recognition of a personal heritage relationship; the ongoing recording of the history of the building; a method of preserving more intangible heritage for built, privately-owned heritage buildings and it would also help develop a sense of guardianship over the home that is passed on to the next owner.

In regards to earthquake strengthening, I would recommend that there is a loosening of the rules and regulations around the incentives, to include private building owners. Earthquake strengthening in the city would benefit from the DCC opening their incentives to private owners, including homeowners. The Wellington City Council has a Built Heritage Incentive Fund, which private owners of heritage registered buildings, including homeowners, are able to apply for. Also, having incentives for non-heritage registered building owners would be beneficial. This would give the non-official heritage homeowners some assistance, especially 
in areas with character streetscapes which are iconic to the city. Improving the communication channels between the authorities and building owners would not only reshape the perceptions of heritage in a more positive light in the community, as mentioned above, but also improve the likelihood that these authorities become the first stop for building owners when they are looking to do earthquake-strengthening work, hopefully in the process decreasing the chances that building owners undertake needless work or be put off by an impossible quote. Lastly, due to the conclusion that heritage homeowners are undertaking earthquake strengthening primarily for safety reasons, I would recommend that councils utilise this motivation in order to encourage more of them to undertake the work.

Many of the ideas and literature referenced in this dissertation were originally written in relation to the museum sector. Their use and application in this research show how interrelated ideas can be applied equally to these sectors. In order for the heritage sector to move forward in their practice of increasingly incorporating intangible heritage into more areas than just indigenous matters I feel that they should be looking to the museum sector. The perception is that museums are organisations serving the community and that the community is a major stakeholder in the museum has lead to relationships based around sharing knowledge, collaboration and partnership. Increasingly museums are calling on relevant sections of the community to assist in the development of exhibitions. It is also relatively common practice around the country for museums to act as the platform for communities to develop their own exhibitions, with museums acting as a support and guide through the process, rather than dictating it. These peoples-based community exhibitions give the community autonomy over how they are represented and places them in control. ${ }^{108}$ These ideas are applied to the heritage conservation sector by Sully, and are especially relevant to the heritage of homes and the relationship between home and homeowner.

Sully's 'peoples-based' heritage conservation prioritises community welfare over materialbased heritage. ${ }^{109}$ Through this approach objects of heritage continue to perform their role within the community, so that old values and meanings are revealed through ongoing interaction. This is an ideal framework for heritage of a domestic nature because houses remain relevant to owners by being used as homes and by being allowed to adapt and change

\footnotetext{
${ }^{108}$ Christy Ballard, 'The negotiation of narratives: a case-study of the Indian community exhibition Aainaa: reflections through Indian weddings (September 2002 - September 2004) at the Museum of New Zealand Te Papa Tongarewa' (MA diss. Victoria University of Wellington Masters Thesis, 2005), 55.

${ }^{109}$ Sully, 2015, 306.
} 
to allow this end. Utilising peoples-based heritage will also enable building owners to see that their own heritage is important, meaning that they may be more likely to make positive heritage conservation decisions. As long as heritage is perceived as defined by authorities, the perception remains that official heritage is the heritage relevant to heritage sites and buildings. Authoritative heritage is effective for heritage that has a closer relationship to the official sphere; it loses its effectiveness in the domestic sphere due to the nature of domestic heritage sites and those that define official heritage. Peoples-based heritage practices would also give heritage homeowners greater autonomy over heritage conservation decisions regarding their homes, and may provide the pathway to improving the perception of heritage protection by private property owners.

All of these points can feed into developing the layperson's understanding of what heritage is and improve the chance that we can develop a cycle of care within the community. A cycle of care within the domestic sphere will encourage heritage homeowners to engage with the various heritage values of their house, and therefore they will be more likely to care for the tangible and intangible heritage, which in turn will make them value it more.

This research has highlighted that it is the people who make a house a home: to keep it useful we must value what these people bring to the building to enable it to remain a home. Heritage values are based on feelings of comfort and intangible stories in which the home is staged as a theatre. This personal relationship with physical heritage elements of the home influences how people look after their homes-ie. undertaking earthquake strengthening in a certain way to preserve elements of the building. However, the primary motivation for this type of structural work is safety. Currently there is room for improvement in the relationship between authorities and homeowners, and this relationship could be improved by increased and more open communication methods and channels between the two. This would likely improve homeowners' perceptions of heritage authorities and should diminish negative perceptions. An improvement in this relationship would most likely provide a platform for authorities to encourage, assist and support homeowners to undertake work, such as earthquakestrengthening, in the future, with less need for legislative provisions. Through this research I have proposed the development of a concept of Domestic Heritage which would provide a theoretical framework which allows scholars and practitioners to take account of and incorporate the unique aspects of the domestic heritage sphere. This theory would work well 
alongside Sully's 'peoples-based' heritage to provide heritage professionals with a method of approaching domestic built heritage in new and more successful ways. 


\section{Bibliography}

\section{Interviews}

DCC Heritage planner. "Research Interview.” Interview by Imogen Stockwell. October 23, 2015.

HNZ Area Manager for Otago and Southland. "Research Interview." Interview by Imogen Stockwell. October 22, 2015.

Homeowner one. "Research Interview." Interview by Imogen Stockwell. November 10, 2015.

Homeowner two. "Research Interview." interview by Imogen Stockwell. November 20, 2015.

Homeowner three. "Research Interview." Interview by Imogen Stockwell. December 11, 2015.

\section{Newspapers}

Otago Daily Times, May 11, 2015

New Zealand Herald, May 10, 2015

\section{Policy}

Dunedin City Council. Earthquake-prone building policy (including provisions for Dangerous and Insanitary Buildings).Dunedin: Dunedin City Council, 2012. http://www.dunedin.govt.nz/_data/assets/pdf_file/0020/155153/EarthquakePolicy.pdf, 3.

\section{Reports}

Canterbury Earthquakes Royal Commission. Final Report: Volume 1-Summary and Recommendations in Volumes 1-3 Seismicity, Soils and the Seismic Design of Buildings. Christchurch: Canterbury Earthquakes Royal Commission, 2012.

Canterbury Earthquake Royal Commission. Final Report: Volume 2-The Performance of Christchurch CBD Buildings. Christchurch: Canterbury Earthquakes Royal Commission, August 2012.

Cowan, Geoffrey Frank. "Dunedin's Heritage: A report Prepared in the City Planning Department, Dunedin City Corporation”. Dunedin: City Planning Department, 1977.

Lancaster, Tom. "The ICOMOS charter and earthquake strengthening of historic buildings". A report submitted in partial fulfilment of the requirements for the degree of Bachelor of Architecture, Victoria University Wellington". 1999.

McClean, Robert. Heritage Buildings, Earthquake Strengthening and Damage: The Canterbury Earthquakes September 2010-January 2012. Wellington: Historic Places Trust New Zealand Pouhere Taonga, 2012. 
Sterne, Craig. "Heritage Conservation in New Zealand: Motivation, processes and applicability". A report submitted in partial fulfilment of the requirements for the degree of Bachelor of Architecture, Victoria University Wellington. 1994.

\section{Thesis}

Mastemaker, Lori. "Memory, Performance, Identity: Making Personal History, Making Meaning: A critical analysis of an independent heritage initiative at Duart House, Havelock North.” MA dissertation. Victoria University of Wellington, 2010.

Smith, Moira. " "A Useful Accessory": The use of lightweight replica ornament to manage the cultural heritage values of earthquake-prone buildings." MA dissertation. Victoria University of Wellington, 2015.

Ballard, Christy. "The negotiation of narratives: a case-study of the Indian community exhibition Aainaa: reflections through Indian weddings (September 2002 - September 2004) at the Museum of New Zealand Te Papa Tongarewa" MA dissertation. Victoria University of Wellington Masters Thesis, 2005.

\section{Websites}

beehive.govt.nz: The Official Website of the New Zealand Government. "More targeted approach to earthquake-prone buildings." Accessed May 10, 2015. https://www.beehive.govt.nz/release/more-targeted-approach-earthquake-pronebuildings

Dunedin City Council. "Heritage Register." Accessed October 31, 2015. http://www.dunedin.govt.nz/council-online/heritage-register.

Dunedin City Council. "Vision." January 9, 2016. https://www.dunedin.govt.nz/whatson/dunedin-heritage/vision.

Hamilton City Council. "Variety 11: Hayes Paddock Heritage Precinct." Accessed May 21. http://www.hamilton.govt.nz/our-council/councilpublications/operativedistrictplan/Pages/Variation-11-.aspx

Heritage New Zealand Pouhere Taonga. "Introduction to Heritage New Zealand." Accessed February 8, 2016. http://www.heritage.org.nz/about-us/introduction.

Heritage New Zealand Pouhere Taonga ."About the List.” Accessed October 31, 2015, http://www.heritage.org.nz/the-list/about-the-list.

McLean, Iain and McMillan, Alistair. The concise Oxford Dictionary of Politics. Oxford: Oxford University Press, 2009. Online version, http://www.oxfordreference.com/view/10.1093/acref/9780199207800.001.0001/acref9780199207800-e-531? rskey $=\mathrm{dnFJ} 4 \mathrm{G} \&$ result $=2$

Oxford Dictionaries: language matters. "Heritage." Accessed May 12, 2015. http://www.oxforddictionaries.com/definition/english/heritage?q=Heritage 
Statistics New Zealand. "2013 Census QuickStats about a place: Dunedin City.” Accessed January 14, 2016. http://www.stats.govt.nz/Census/2013-census/profile-andsummary-reports/quickstats-about-a-place.aspx?request_value=15022\&tabname.

Te Ara: The Encyclopedia of New Zealand. "Waikato places-Hamilton east of the river". Last modified July 13, 2012. http://www.TeAra.govt.nz/en/waikato-places/page-8.

\section{Conference Papers}

Egbelakin, Temitope; Wilkinson, Suzanne. "Factors Affecting Motivation for Improving Seismic Retrofit Implementation.” Australian Earthquake Engineering Conference AFES November 2008.

Tomaszewski, Andrzej. Values and Criteria in Heritage Conservation. Proceedings of the International conference of ICOMOS, ICCROM and Fondazione Romualdo Del Bianco, 2-4 March 2007 Florence. Florence: Polistampa, 2008.

\section{Journal Articles}

Knight, Hardwick. "Dunedin's Heritage”. In Historic places in New Zealand volume 12, 1988: 26-27.

Thomas, Graham. "The Case: generalisation, theory and phronesis of case study". In Oxford Review of Education, vol 37, no 1 (2011): 21-35.

Wain, Alison. "Conservation of the intangible: a continuing challenge." AICCM Bulletin 35 (2014): 52-59.

Witcomb, Andrea. "Understanding the role of affect in producing a critical pedagogy for history museums." Museum Management and Curatorship 28, 3 (2013): 255-271.

\section{Books and Edited Collections}

Bechhofer, Frank and Paterson, Lindsay. Principles of Research Design in the Social Sciences. London: Routledge, 2000.

Benton, Tim. Understanding Heritage and Management. Manchester: Manchester University Press, 2010.

Brooks, Barbara. At Home in New Zealand: History, Houses, People. Wellington: Bridget Williams Books, 2000.

Corsane, Gerard. Heritage, Museums and Galleries: An Introductory Reader. Abingdon: Routledge, 2005.

Crooke, Elizabeth. Museums and Community: ideas, issues and challenges. Abingdon: Routledge, 2007. 
Denscombe, Martyn. The Good Research Guide: For small-scale social research projects. Maidenhead: Open University Press, 2010.

Elliot, J. Using Narrative in Social Research. London: Sage Publications Limited, 2005.

Findlay, Michael. Dunedin Contextual Thematic History. Prepared for the Dunedin City Council, 2009.

Gatley, Julia and Walker, Paul. Vertical living: the Architectural Centre and Remaking of Wellington. Auckland: Auckland University Press, 2014.

Gilbert, N. Researching Social Life. Los Angeles: Sage Publications Limited, 2008.

Harrison, Rodney. Heritage: Critical Approaches. London: Routledge, 2013.

Harrison, Rodney. Understanding the Politics of Heritage. Manchester: Manchester University Press, 2010.

ICOMOS. ICOMOS New Zealand charter for the conservation of places of cultural heritage value. Auckland: ICOMOS New Zealand, 1993.

Kernohan, David. Wellington's New Buildings. Wellington: Victoria University Press, 1989.

McCarthy, Conal. Museums and Māori: heritage professionals, indigenous collection, current practice. Walnut Creek: Left Coast Press, Inc., 2011.

McLean, Gavin. Dunedin: History, Heritage and Wildlife. Dunedin: University of Otago Press, 2003.

New Zealand Historic Places Trust. Historic Buildings of New Zealand: South Island. Auckland: Methuen Publications (N.Z.) limited, 1983.

O’Reilly, Karen. Key concepts in Ethnography. London: Sage Publications, 2009.

Peat, Neville. Heritage Dunedin. Dunedin: Hyndman Publishing, 1993.

Robertson, Iain J M. Heritage from Below. Surrey: Ashgate Publishing Limited, 2014.

Rybezynski, Witold. Home: A short history of an idea. New York: Penguin Books, 1986.

Schofield, John. Who needs Experts? Counter-mapping Cultural Heritage. Surrey: Ashgate Publishing Limited, 2014.

Schrader, Ben. We Call it Home: a History of State Housing in New Zealand. Auckland: Reed Publishing, 2005.

Shaw, Peter. New Zealand Architecture: From Polynesian Beginnings to 1990. Auckland: Hodder and Stoughton, 1991. 
Smith, Laurajane. Cultural Heritage: Critical Concepts in Media and Cultural Studies. London: Routledge, 2007.

Smith, Laurajane. Uses of Heritage. Abingdon: Routledge, 2006.

Stig Sørensen, Marie Louise and Carman, John. Heritage Studies: Methods and Approaches. London: Routledge, 2009.

Sully, Dean. "Conservation Theory and Practice: Materials, Values, and People in Heritage Conservation". In The International Handbook of Museum Studies: Museum Practice, edited by Conal McCarthy 293-314. Milton: John Whiley and Sons 1td, 2015.

Trapeznik, Alexander. Common Ground? Heritage and Public Places in New Zealand. Dunedin: University of Otago Press, 2000.

Trapeznik, Alexander. Dunedin's Warehouse Precinct. Dunedin: Genre Books, 2014.

UNESCO. "Basic Texts of the 1972 World Heritage Convention". Fontenoy: UNESCO, 2005.

Uzzell, David. "Where is the Discipline in Heritage Studies: A view from environmental psychology". In Heritage Studies: Methods and Approaches, edited by Marie Louise Stig Sørensen and John Carman, 326-333. London: Routledge, 2009.

Ward, Peter. A History of Domestic Space: Privacy and the Canadian Home. Toronto: UBC Press 1999.

Waterton, Emma and Watson, Steve. Heritage and Community Engagement: Collaboration or Contestation? Abingdon: Routledge, 2011.

Watson, Sheila. Museums and their Communities. Edited by Sheila Watson. London: Routledge, 2007.

West, Susie. Understanding heritage in Practice. Manchester: Manchester University Press, 2010. 


\section{Appendix one: \\ Questions from the interview with the DCC Heritage Planner}

\section{Background information about heritage homes in Dunedin:}

1. How does a domestic dwelling become a listed heritage building by the DCC?

2. What is the role of the homeowner in this process?

3. What does the DCC do to promote the development of a cycle of care for built heritage within the community?

4. In domestic dwellings how does the DCC acknowledge and assist in the preservation of intangible heritage?

5. How do you balance preserving built heritage fabric and remembering that a building such as a home needs to be allowed to adapt and change in order to remain useful?

6. Does the DCC assist homeowners in recognising that their personal connection to their house is of heritage value? And if so, what mechanisms are in place to achieve this?

DCC action on earthquake strengthening:

7. How has the DCC's policy on earthquake prone buildings changed over the last 4 years?

8. How have the incentives been received by building owners?

9. Have homeowners been accessing the incentives that the DCC has to aid heritage building strengthening? If so, what type of strengthening are they predominantly accessing?

This leads us into the final section discussing motivations for domestic strengthening.

10. In your experience working for the DCC, have you noticed any of the motivating factors behind conservation work such as earthquake strengthening?

That brings us to the end of the interview, do you have any last comments? 


\section{Appendix two: \\ Questions from the interview with \\ HNZ Area Manager Otago and Southland}

\section{Background information about heritage homes in Dunedin:}

1. How does a domestic dwelling become a listed heritage building by $\mathrm{HNZ}$ and what role does the homeowner have in this process?

2. What does HNZ do to promote the development of a cycle of care for build heritage within the community?

3. In domestic dwellings how does HNZ acknowledge and assist in the preservation of intangible heritage?

4. How do you balance preserving built heritage fabric and remembering that a building such as a home needs to be allowed to adapt and change in order to remain useful?

5. Does HNZ assist homeowners in recognising their personal connection to their house is of heritage value? And if so, what mechanisms are in place to achieve this?

\section{Earthquake Strengthening:}

6. How is HNZ working with the DCC to encourage the earthquake strengthening of heritage buildings?

7. Are there any measures that HNZ have taken, independent of the DCC, to aid, promote and encourage earthquake strengthening? And what are these?

8. How do domestic dwellings fit into this?

This leads us into the final section discussing motivations for domestic strengthening:

9. In your experience working for HNZ, have you noticed any of the motivating factors behind conservation work such as earthquake strengthening?

That brings us to the end o the interview, do you have any last comments? 


\section{Appendix three:}

\section{Questions from the interview with Homeowner one}

1. How long have you lived in this house?

2. Have you raised any children here?

\section{Official Heritage:}

3. Was the house classified as a heritage building when you purchased it?

4. Were you aware of the classification at the time of purchase?

5. Do you know why it is classified?

6. Has its classification impacted decisions making when it comes to making changes to the house?

7. Do you think that current homeowners should have more input into how the protection of the house is at the moment? So, do you feel that you should be able to, as the current homeowner, be able to have more say over what you can do and the way it's protected?

8. Say your house wasn't a listed heritage building, but it did come up under the Council's plan to list, and you were consulted as to what should be protected and how it should be protected. What aspect would you choose, as being important and what protection would you seek?

\section{Personal Heritage:}

9. What is your favourite thing about your home? You could choose anything about it, or any feature, it could be physical or non-physical.

10. In your opinion, what makes it a home rather than being a house you reside in?

11. What alterations have you made to the home, whilst you have been living there?

12. As the house stands now, if you could change anything about the house, what would it be?

13. What is the principle thing preventing you from doing these things?

14. Have you ever considered demolishing the house and starting again? If you legally could.

15. If you could pick one memory involving this house, what would it be? It could be an event, a life moment, or a family story that everyone remembers. 
16. How do you think you and your family are now part of the heritage of this house? How do you think you have contributed to it?

17. If you were to sell the property, are there any aspects of the house that you changed or added to, which you would be really sadden by if the new owner suddenly changed or significantly alter?

\section{Earthquake strengthening:}

18. What work have you undertaken?

19. You mentioned before that it was initially to give you space in the kitchen, and that was the main reason for initiating the work and then the further stuff was to strengthen?

20. May I ask how much it cost you to do the work that would be classified as strengthening?

21. Did you receive any financial aid for the work you did?

22. When you did the work, did you know about funding opportunities through either HNZ or the DCC?

\section{Is there anything else you would like to add?}

23. Of your own lives that have happened there, if you were to sell it to someone, would you be interested in sharing some of your memories with them, in some way. Say having some photos of your life there attached to the file, accessible... 


\section{Appendix Four: \\ Questions from the interview with Homeowner two}

1. How long have you lived in your home?

2. Have you raised any children in your home?

\section{Official Heritage:}

3. Should your home be registered as a heritage building?

4. If your house was to be classified how do you perceive a classification impacting changes you make to your house, future changes to make your house?

5. Do you think that current homeowners should have more input into what about their houses are protected and how they are protected?

6. If your house was to come up for protection, what aspects would you choose to protect and what level of protection would you choose?

\section{Personal Heritage:}

7. What is your favourite thing about your home? And in your opinion, what makes it a home?

8. What alterations have you made to your home while you have been there?

9. If you could change anything about your house right now, what would it be? You can dream.

10 . What is preventing you from doing that?

11. Have you ever considered demolishing your house and starting again?

12. If you had to pick one memory or story involving your house, what would it be?

13. How do you think that you and your family become part of the heritage of the house?

14. If you were to sell the property are there any aspects of the house that you have changed that you would feel saddened if the owner dramatically changed or significantly altered?

\section{Earthquake strengthening:}

16. What earthquake strengthening have you undertaken?

17. When abouts did you do that work?

18 . What is your house constructed of?

19. How much did the earthquake strengthening cost you?

20. Did you receive any financial aid to do the work? 
21. If you were to sell your house and there was the opportunities to attach some of your memories or images, to show that you lived a life in this house, would you take up that opportunity?

22. Is there anything else you would like to add? 


\section{Appendix Five:}

\section{Questions from the inveterview with Homeowner three}

1. How long have you lived in your home?

2. Have you raised any children in your home?

\section{Official Heritage:}

3. Is your house a heritage listed building?

4. What is the age of your house?

5. What is the history of your house?

6. How do you feel your house contributes to the heritage of Dunedin or New Zealand?

7. Do you think it should be classified?

8. If your house was to be classified how do you perceive a classification impacting what you can do to your house or your rights as a homeowner?

9. Based on your perception of protection, do you think that current homeowners should have more input on what about their house is protected and how it is protected?

10. If your house was to come up for protection, what aspects would you choose to protect and what aspects would you choose to protect?

\section{Personal Heritage:}

11. What is your favourite thing about your home?

12. In your opinion, what makes it a home?

13. What alterations have you made to your home while you have been there?

14. If you could change anything about your house right now, what would it be? You can dream.

15 . What is preventing you from doing that?

16. Have you ever considered demolishing your house and starting again?

17. If you had to pick one memory or story involving your house, what would it be?

18. How do you think that you and your family become part of the heritage of the house?

19. If you were to sell the property are there any aspects of the house that you have changed that you would feel saddened if the owner dramatically changed or significantly altered?

\section{Earthquake strengthening:}

20. Could you go through and list what earthquake strengthening you have done? 
21. And why did you do the strengthening work?

22. How much did the earthquake strengthening cost you?

23. Did you receive any financial aid to do the work?

24. If you were to sell your house and there was the opportunities to attach some of your memories or images, to show that you lived a life in this house, would you take up that opportunity?

25. Is there anything else you would like to add? 
